\title{
Petrography, Mineralogy, and Geochemistry of Combustion Metamorphic Rocks in the Northeastern Ordos Basin, China: Implications for the Origin of "White Sandstone"
}

\author{
Bin Chen ${ }^{1,2}$, Yanyan Wang ${ }^{3}$, Marco Franceschi ${ }^{4}$, Xiong Duan ${ }^{5}$, Kuizhou Li ${ }^{2}, \mathrm{Yu} \mathrm{Yu}^{1}$, \\ Meiling Wang ${ }^{2}$ and Zhiqiang Shi ${ }^{1,2, *}$ \\ 1 State Key Laboratory of Oil and Gas Reservoir Geology and Exploitation, Chengdu University of Technology, \\ Chengdu 610059, China; chenbin@stu.cdut.edu.cn (B.C.); yuyu@cdut.edu.cn (Y.Y.) \\ 2 Institute of Sedimentary Geology, Chengdu University of Technology, Chengdu 610059, China; \\ likuiz90@163.com (K.L.); wangmeilingh@163.com (M.W.) \\ 3 College of Materials, Chemistry and Chemical Engineering, Chengdu University of Technology, \\ Chengdu 610059, China; yy_wang320@163.com \\ 4 Department of Mathematics and Geosciences, University of Trieste, via E. Weiss 2, 34128 Trieste, Italy; \\ mfranceschi@units.it \\ 5 School of Land and Resources, China West Normal University, Nanchong 637009, China; \\ duanxiong00@163.com \\ * Correspondence: shizhiqiang@cdut.edu.cn
}

Received: 7 October 2020; Accepted: 30 November 2020; Published: 3 December 2020

\begin{abstract}
Since the Quaternary period, tectonic uplift and river erosion in the northeastern Ordos Basin (northwest China) have exhumed numerous coal seams, creating the conditions for the development of coal fires following their spontaneous combustion or other types of ignition (e.g., lightning strikes). Coal fires activity is testified by the widespread occurrence of combustion metamorphic rocks. In this study, thin section analyses, scanning electron microscopy, X-ray diffraction (XRD), X-ray fluorescence (XRF), and inductively coupled plasma mass spectrometry (ICP-MS) were used to investigate in detail the mineralogical and geochemical characteristics of combustion metamorphic rocks in the Jurassic succession of the northeastern Ordos Basin. The samples collected in localities distributed over an area of about $8000 \mathrm{~km}^{2}$ were analyzed to determine their mineral association, revealing the presence of tridymite, cristobalite, mullite, and cordierite that are typically produced in pyrometamorphic reactions. XRF and ICP-MS analyses revealed that combustion metamorphic rocks are iron-enriched. Investigations in the study area also highlighted the occurrence of a peculiar, porous, and permeable white sandstone that appears often associated with clinkers or coal seams. It is composed of quartz and feldspar grains and cemented by kaolinite. It is here suggested that the white color of this sandstone could be due to coal fire-related kaolinization of a sandstone protolith produced by the acidic low-temperature hydrothermal circulation of rain waters during times of coal fire activity.
\end{abstract}

Keywords: combustion metamorphic rocks; ordos basin; clinker; white sandstone; low-temperature hydrothermal circulation; kaolinization

\section{Introduction}

Combustion metamorphic $(\mathrm{CM})$ rocks are products formed by spontaneous combustion of coal, gas, or other organic matter, and pyrometamorphism is the process of high temperature/low pressure metamorphism of sediments caused by combustion [1-4]. This process results in dehydration, dehydroxylation, and decarbonation of sedimentary parent rocks. Spontaneous combustion of coal 
seams is not uncommon where coal seams-bearing units are exposed, and causes baking or melting of the surrounding sedimentary protoliths. Two of the most common products of coal seam combustion are clinker and paralava. Clinker is baked, unmelted, or partially melted, reddish rock, and it is not related to the original rock. Paralava is aphanitic, vesicular, completely fused rock [1,5-7]. The petrology, mineralogy, and geochemistry of CM rocks depend on the composition of the protolith, degree of oxidation, and fusion state [8,9]. CM rocks contain characteristic high-temperature minerals that derive from the recrystallization and reactive interaction of sedimentary minerals during the combustion of coal seams [10-12]. These typical minerals include leucite, mullite, cristobalite, hematite, tridymite, and cordierite, and reflect the variable temperature regime of pyrometamorphism [13-17]. CM rocks are observed worldwide. For instance, they are reported in India, USA, Russia, Europe, Israel, and South Africa [1,4,18-24]. CM rocks are normally more resistant to erosion than the surrounding unbaked rocks and form buttes, ridges, and terraces, so their presence often affects surface morphology $[1,25,26]$.

In China, the CM complexes are mainly distributed in the northwest of China and are particularly concentrated at the margins of orogenic belts (e.g., Tianshan Orogen) or at the edges of the sedimentary basins (e.g., Junggar, Yili, Tuha, Tarim, and Ordos Basins) [21,27-31]. This is the result of extensive coal seam distribution and arid climate conditions [20].

In the northeastern Ordos Basin, CM rocks are mainly distributed in the sides of valleys and gullies, with a thickness ranging from 3 to $10 \mathrm{~m}$. [21,32]. Huang (2008) revealed three stages of large-scale coal fires occurred in the northeastern Ordos Basin through fission track dating of CM rocks: Late Cretaceous, Late Eocene, and Late Miocene [33]. Ye et al. (1998) and Sun et al. (2001) used K-Ar dating to estimate the ages of CM rocks in the south and north of Tianshan Mountain, which were $3.26 \pm 0.3 \mathrm{Ma}$ and $2.33 \pm 0.2 \mathrm{Ma}$, respectively [34,35]. The ages of CM rocks are similar to those of Goose Lake Coal Basin and Kuznetsk Coal Basin, and their ${ }^{40} \mathrm{Ar} /{ }^{39} \mathrm{Ar}$ ages revealed that large-scale coal fires occurred in two stages, in the Early Pleistocene and Late Pleistocene [17,18,36,37]. Since the late Cenozoic, the Ordos Basin has been rapidly uplifted resulting from the uplift of the Qinghai-Tibet plateau [38-40]. Due to this process, the surface has constantly been eroded, and a series of NW-SE and S-N oriented rivers valleys developed in the northeastern Ordos Basin [41]. In the Quaternary period, along with the continuous uplift of the basin, the fluvial headward erosion has continued, resulting in part of the Jurassic coal-bearing strata being exposed on both sides of the river valley. This created the conditions for the ignition of coal seams following spontaneous coal oxidation, smoldering and combustion caused by lightning strikes, forest, bush or steppe fires, etc. [1,25,42-44]. The result is that the $\mathrm{CM}$ rocks, as the erosion-resistant unit formed by coal fires, are mainly distributed on valley sides of tributaries of the Yellow River [21,32,45] (Figure 1b).

In China, most studies have focused on the mechanisms of spontaneous combustion of coals and detection and extinguishing of modern coal fires [20,46-49]. Less attention has been dedicated to the investigation of the macroscopic and microscopic characteristics of CM rocks in the area $[7,21,28]$. This paper describes the field occurrences of the CM rocks produced by coal fires in the northeastern Ordos basin. We applied a number of analytical techniques to characterize petrography, mineralogy, and whole-rock chemistry of such rocks in detail, revealing the complex combustion metamorphic processes they have undergone.

In addition, we report the occurrence of a peculiar white sandstone that is commonly associated with CM rocks in the study area. White sandstone facies has been reported in Southeastern Utah and central Germany [50-53], and it was suggested that it might have originated from the bleaching process of an original red sandstone protolith. Moreover, some researchers also proposed that the white sandstone in the northeastern Ordos basin derived from bleaching of an original red sandstone [54,55]. They suggested that hydrocarbons spilling to the surface in the basin acted as reducing agents, and bleached red sandstone into white sandstone. This process, however, remains largely unclear. We tried to assess this question through a series of analyses as well as comparing and contrasting with white sandstone occurrences in other parts of the world. We noticed that the rock in contact with the white sandstone in our study area is not red sandstone, but red clinker, which is the product of 
spontaneous combustion of coal since the Quaternary period. The red color of the clinker is controlled by the hematite formed during combustion metamorphism [56-58], not the color of the protolith, and this is the most fundamental difference from other regions. Combining the temporal and spatial relationship between white sandstone and red clinker in the study area, as well as their mineralogical and geochemical characteristics, we propose a genetic model for the origin of these characteristic facies in northwestern China.
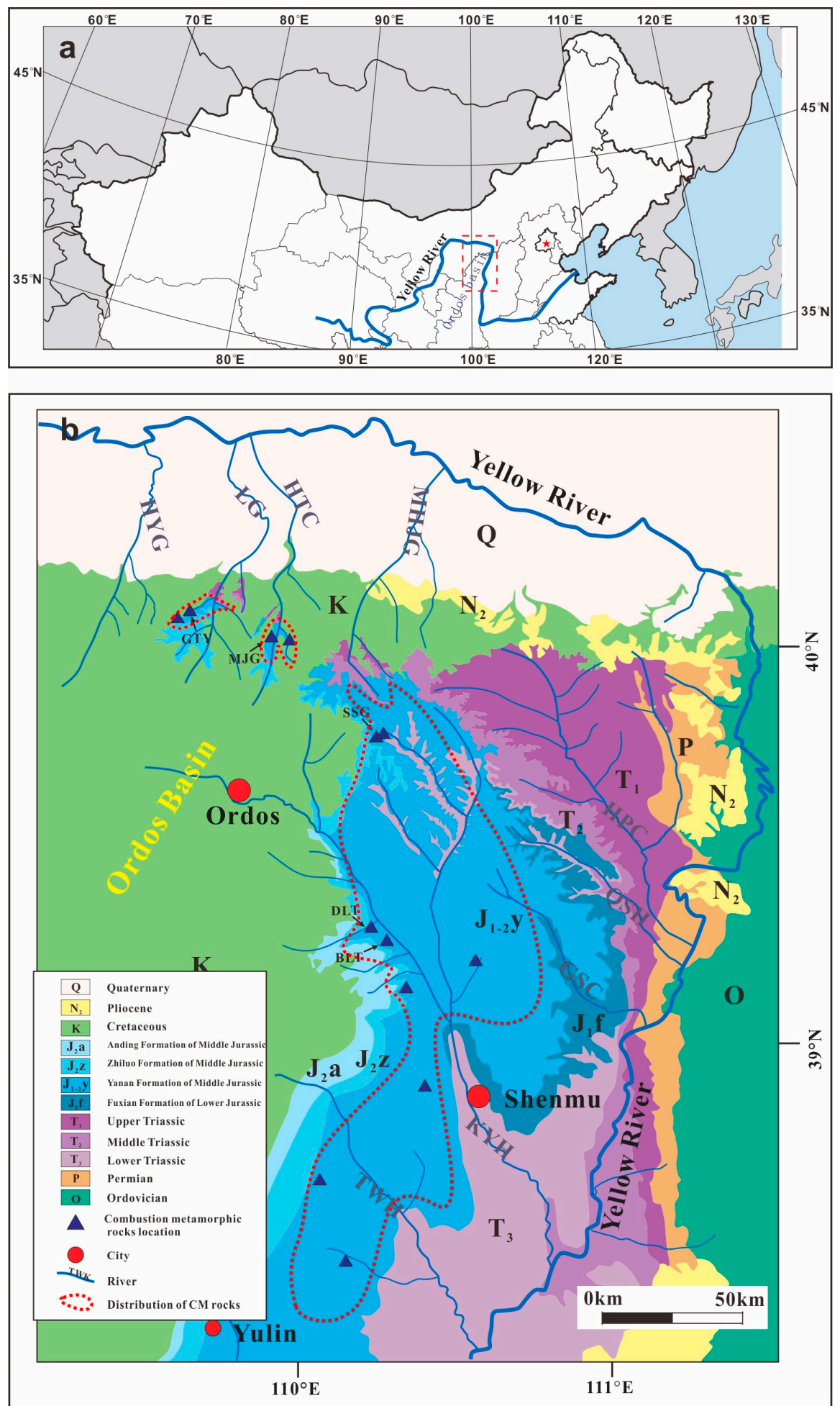

Figure 1. (a) Location map of the study area (dotted rectangle) in North China. (b) Geological map of the northeastern Ordos Basin showing the distribution of combustion metamorphic rocks [21,32,45]. 


\section{Geological Setting}

The Ordos Basin is located in northern China, adjacent to the northeastern Tibetan Plateau. It is a large intra-continental basin surrounded by graben $[59,60]$. The Yellow River, originating from the northeastern margin of the Tibet Plateau, flows across the basin through a large rectangular bend (Figure 1a) [60].

As a Mesozoic continental basin, the Ordos Basin hosts a succession of Triassic to late Jurassic terrestrial clastic deposits [61]. The Triassic units comprise sandstone interbedded with mudstone or shale, referred to as a lacustrine environment [62]. The Jurassic strata are mainly composed of light grey siltstone and coal seams, including the Fuxian Formation of the Lower Jurassic and the Anding Formation, Zhiluo Formation, and Yan'an Formations of the Middle Jurassic [63]. In the northeastern Ordos Basin, the Triassic and Jurassic outcrop westward (Figure 1b) is unconformably covered by Neogene red clay (sometimes conglomerates) and Quaternary loess deposits [38,64].

The coal-bearing deposits of the basin consist of Carboniferous, Permian, and Jurassic strata. Multiple sets of thick coal beds characterized by simple structure and shallow burial depth developed in the Early and Middle Jurassic strata [65] and are widely distributed throughout the basin. The total thickness of coal-bearing beds is about $300 \mathrm{~m}$ [66]. In particular, the Yan'an Formation is the major coal-bearing strata in the Ordos Basin, and the coal seams are the most widely distributed and shallowly buried $[67,68]$. The coal seam of the Yan'an Formation in the study area is divided into nine coal beds. The minimum coal bed thickness is $8.25 \mathrm{~m}$, the maximum is $30 \mathrm{~m}$, and the average is $15-20 \mathrm{~m}$. As a result of the long-term development of the superimposed basin, the Carboniferous-Permian sequence appeared in the east of the basin and was commonly exposed on banks of the Yellow River [69]. The macroscopic petrographic types of these Jurassic coals are mainly semi-dull and dull coal [65]. Especially in the area near the northern margin of the basin, the proportions of semi-dull and dull coal are higher [33,70]. Coals are dominated by inertinite (14.7-85.6\%) and vitrinite (8.5-77.7\%) [71]. The coal in the study area is low-metamorphic bituminous coal, and its coal rank is relatively low. The volatile matter content is generally around $37 \%$, and the vitreous reflectance is generally $0.5-0.61 \%$ [72].

During the Late Cretaceous to Paleogene period, most of the Ordos Basin was uplifted and denuded [35]. In the Early Neogene, fault basins or graben systems formed in the surrounding area of the Ordos Block, forming a new Ordos Basin [73]. Subsequently, the Ordos Basin has been uplifted as a whole owing to the eastward extrusion of the Tibet Plateau [74,75], and it completed the transition from basin to plateau in the late Miocene-Pliocene period $[38,76]$. The middle reach of the Yellow River formed during this period [60]. In the Quaternary period, the rapid uplift of the Ordos Basin and the complete connection of the Yellow River at $0.15 \mathrm{Ma}[77,78]$ resulted in intensified erosion of the Yellow River and its tributaries [39,41,75].

Under the control of neotectonic movement since the late Miocene, the overall uplift of the Ordos Basin and the continuous subsidence of the surrounding graben basin resulted in differential uplift and intense erosion in the basin [74-76]. Especially, the formation of the Shanxi-Shaanxi Gorges in the early Pleistocene prompted the rapid downward erosion of the Yellow River and the headward erosion of the tributaries on the west side of the Yellow River, forming the geomorphic ravine features of the study area $[42,79,80]$. With the erosion and collapse of the river, the fresh coal seams were exposed to the air $[38,43]$. Coal seams with low-rank, high-volatility, and medium thickness in the study area are prone to spontaneous combustion [20]. The Ordos Basin became significantly arider during the Quaternary period resulting from the barrier effect exerted by the Tibet Plateau on Asian monsoon circulation $[38,81,82]$. All this created favorable conditions for the spontaneous ignition of the coal seam and the development of coal fires. Because of the volume loss of the underground coal seam during the combustion process, surface collapse in the coal fire areas is common, forming bedrock surface fracturing [83]. The resulting fracturing allows air to enter and gas to escape so that the coal fires continue [1,5].

In the Ordos Basin, $\mathrm{CM}$ rocks are mainly distributed in the northwest (i.e., the Wuda coal mine) and northeast of the basin. The coal fires in the Wuda coal mine were caused by coal mining and 
are currently still burning [30,31,84]. So far, they are estimated to have consumed about $1.3 \mathrm{Mt}$ of coal [31]. In the northeastern Ordos Basin, the CM rocks are mainly distributed at end of branches of the Liugou River (LG) and Hantaichuan River (HTC) in the northern part of Ordos city and around branches of the Kuyehe River (KYH) and Tuweihe River (TWH) in the eastern part of Ordos city. $\mathrm{CM}$ rocks are scattered in the sides of valleys and gullies, and their main distribution range is about $8000 \mathrm{~km}^{2}[21,28,32,45]$.

The study area is located in the northeastern part of the Ordos Basin. In the study area, the topography extends southeast, with a mean altitude of 1000-1500 m [41]. A series of NW-SE oriented rivers developed east of the Ordos Basin: Huangpuchuan River (HPC), Qinshuihe River (QSH), Kuyehe River (KYH), and Tuweihe River (TWH). In addition, rivers are flowing from south to north: Heiyaogou River (HYG), Liugou River (LG), Hantaichuan River (HTC), and Muhujungou River (MHJG). All these rivers are tributaries of the Yellow River (Figure 1b).

\section{Materials and Methods}

A total of 78 samples of $\mathrm{CM}$ rocks (including clinker, porcellanite, and paralava) and white sandstone were collected from outcrops in the Bailiutu (BLT), Shenshangou (SSG), Gaotouyao (GTY), Mujiagou (MJG), and Daliuta (DLT) Areas (Figure 1).

Fifty-four thin sections were prepared and photographed with a NikonLV100POL petrographic microscope at the Institute of Sedimentary Geology, Chengdu University of Technology, China.

Seventeen samples were examined using a Quanta 250 FEG scanning electron microscope (SEM) at the State Key Laboratory of Oil and Gas Reservoir Geology and Exploitation of the Chengdu University of Technology. The samples were gold-coated using a sputtering coater and then the images were captured via a retractable solid-state backscattered electron detector. The working distance of the FESEM-EDS was $10 \mathrm{~mm}$, with a beam voltage of $20.0 \mathrm{kV}$, aperture 6, and a spot size of 4.5-5.5 $\mu \mathrm{m}$.

Four CM rock powder samples, including clinker and paralava samples, were analyzed by $\mathrm{X}$-ray powder diffraction (XRD) using a Rigaku Ultima IV XRD diffractometer with $\mathrm{Cu}-\mathrm{K} \alpha$ radiation and a $\mathrm{D} /$ teX Ultra detector in the College of Materials and Chemistry \& Chemical Engineering at the Chengdu University of Technology, China. The X-ray intensities were measured in the range of 5-50 $2 \theta$ with a scanning rate of $20^{\circ} / \mathrm{min}$ operating at $40 \mathrm{kV}$ and $40 \mathrm{~mA}$. Clay mineral concentrations of four white sandstone samples from the SSG area (SSG-D-6, SSG-F-2, SSG-F-3, and SSG-F-4) were analyzed using X-ray powder diffraction.

A total of 12 samples, including clinker, paralava, and white sandstone, from BLT (4), DLT (4), SSG (3), and MJG (1) areas, were analyzed for major element concentrations. Whole-rock analyses of the major elements of combustion metamorphic rocks were carried out using X-ray fluorescence (XRF) in the mass spectrometry laboratory of the College of Materials and Chemistry \& Chemical Engineering at the Chengdu University of Technology.

Three samples (paralava and clinker) from BLT were analyzed for trace elements. Trace elements were analyzed using ICP-MS at ALS Chemex (Guangzhou) Co., Ltd. The results are listed in Tables 1 and 2. 
Table 1. Major element composition (wt.\%) of combustion metamorphic rocks.

\begin{tabular}{|c|c|c|c|c|c|c|c|c|c|c|c|c|}
\hline \multirow{3}{*}{$\begin{array}{c}\text { Section } \\
\text { Sample } \\
\text { No. }\end{array}$} & \multicolumn{4}{|c|}{ BLT } & \multicolumn{4}{|c|}{ DLT } & \multicolumn{3}{|c|}{ SSG } & \multirow{2}{*}{$\begin{array}{c}\text { MJG } \\
\text { S-12 }\end{array}$} \\
\hline & S-1 & $\mathrm{S}-2$ & S-3 & S-4 & S-5 & S-6 & S-7 & S-8 & S-9 & S-10 & S-11 & \\
\hline & BLT-1 & BLT-13 & BLT-17 & BLT-5 & DLT-1 & DLT-2 & DLT-3 & DLT-4 & SSG-C-1 & SSG-C-2 & SSG-F-2 & MJG- \\
\hline Lithology & Paralava & Clinker & Clinker & White Sandstone & Clinker & Paralava & Paralava & Clinker & Clinker & Clinker & White Sandstone & Clinker \\
\hline $\mathrm{SiO}_{2}$ & 61.10 & 65.47 & 62.99 & 65.99 & 61.49 & 67.82 & 62.38 & 58.26 & 59.75 & 58.42 & 69.41 & 61.83 \\
\hline $\mathrm{TiO}_{2}$ & 0.90 & 0.77 & 0.93 & 1.37 & 0.92 & 0.66 & 0.63 & 0.90 & 0.72 & 0.91 & 0.98 & 0.73 \\
\hline $\mathrm{Al}_{2} \mathrm{O}_{3}$ & 23.32 & 16.76 & 20.97 & 22.94 & 23.27 & 16.27 & 16.22 & 21.89 & 23.19 & 24.23 & 23.00 & 19.49 \\
\hline $\mathrm{TFe}_{2} \mathrm{O}_{3}$ & 5.97 & 3.74 & 4.39 & 0.66 & 4.10 & 5.06 & 3.24 & 8.65 & 3.93 & 4.93 & 0.91 & 5.46 \\
\hline $\mathrm{MnO}$ & 0.04 & 0.03 & 0.03 & 0.02 & 0.03 & 0.03 & 0.17 & 0.23 & 0.04 & 0.04 & 0.02 & 0.04 \\
\hline $\mathrm{MgO}$ & 1.26 & 0.93 & 0.6 & 0.19 & 1.18 & 0.72 & 0.82 & 2.19 & 1.98 & 2.28 & 0.55 & 2.51 \\
\hline $\mathrm{CaO}$ & 0.77 & 3.93 & 1.33 & 0.14 & 0.69 & 0.53 & 7.41 & 2.03 & 0.62 & 0.57 & 0.36 & 0.70 \\
\hline $\mathrm{Na}_{2} \mathrm{O}$ & 0.28 & 1.19 & 0.31 & 0.17 & 0.31 & 1.22 & 1.58 & 0.24 & 1.19 & 0.45 & 0.19 & 0.35 \\
\hline $\mathrm{K}_{2} \mathrm{O}$ & 1.96 & 2.34 & 0.41 & 2.69 & 1.90 & 2.58 & 1.70 & 0.38 & 2.77 & 2.75 & 3.32 & 2.71 \\
\hline $\mathrm{P}_{2} \mathrm{O}_{5}$ & 0.13 & 0.17 & 0.10 & 0.06 & 0.15 & 0.12 & 0.24 & 0.08 & 0.18 & 0.15 & 0.03 & 0.12 \\
\hline $\mathrm{SO}_{3}$ & 0.65 & 0.18 & 1.00 & 0.03 & 0.35 & 0.04 & 0.07 & 0.07 & 0.10 & 0.02 & 1.05 & 0.11 \\
\hline $\mathrm{SrO}$ & 0.03 & 0.03 & 0.03 & 0.01 & 0.02 & 0.01 & 0.02 & 0.04 & 0.01 & 0.01 & 0.01 & 0.02 \\
\hline LOI & 4.25 & 4.29 & 6.85 & 5.35 & 5.39 & 4.71 & 5.28 & 4.85 & 5.07 & 5.07 & & 5.67 \\
\hline
\end{tabular}

Table 2. Trace element $(\mu \mathrm{g} / \mathrm{g})$ composition of combustion metamorphic rocks.

\begin{tabular}{cccccccccccccccccccccc}
\hline Sample No. & $\mathbf{R b}$ & $\mathbf{B a}$ & $\mathbf{T h}$ & $\mathbf{U}$ & $\mathbf{N b}$ & $\mathbf{L a}$ & $\mathbf{C e}$ & $\mathbf{P b}$ & $\mathbf{S r}$ & $\mathbf{N d}$ & $\mathbf{Z r}$ & $\mathbf{H f}$ & $\mathbf{S m}$ & $\mathbf{E u}$ & $\mathbf{T b}$ & $\mathbf{Y b}$ & $\mathbf{L u}$ & $\mathbf{Y}$ & $\mathbf{S c}$ & $\mathbf{V}$ & $\mathbf{N i}$ \\
\hline BLT-1 & 103 & 600 & 19.5 & 3.92 & 17.3 & 54.8 & 106 & 5 & 253 & 38.5 & 157 & 4.4 & 7.31 & 1.64 & 1.00 & 3.70 & 0.56 & 32.1 & 22.3 & 165 & 33.5 \\
BLT-13 & 82.8 & 635 & 17.35 & 3.09 & 14.4 & 68.1 & 133.5 & 14.6 & 188 & 57.4 & 289 & 7.4 & 10.95 & 2.27 & 1.22 & 2.82 & 0.40 & 30.2 & 17.7 & 93 & 37.8 \\
BLT-17 & 5.3 & 2010 & 20.0 & 2.66 & 16.2 & 67.0 & 136 & 774 & 246 & 57.8 & 499 & 13.3 & 11 & 1.92 & 1.46 & 4.28 & 0.63 & 38.0 & 19.4 & 79 & 37.3 \\
\hline
\end{tabular}




\section{Results}

\subsection{Petrography of Combustion Metamorphic Rocks and White Sandstones from the Northeastern Ordos Basin}

\subsubsection{Main Types of CM Rocks and Their Macroscopic Characteristics}

The clinkers are partly fused after heating and baking but inherit partly the original texture of precursor sedimentary parent rocks and are widely distributed in the study area. The clinkers usually have a red color (Figure $2 \mathrm{a}-\mathrm{c}$ ) and occasionally display columnar jointing (Figure 2e). The columns are 5-20 cm long and reach 5-10 $\mathrm{mm}$ in diameter. In addition, condensing shrinkage pores and fractures are common in the clinkers and are partly filled with calcite (Figure 2f,g). In some clinker samples, traces of plant fragments were found (Figure $2 \mathrm{~h}$ ). Moreover, there is a kind of CM rock that has undergone thermal alteration (slight baking) but has not been melted. The baked rock retains the characteristics of the protolith, and the color is light red due to baking.

The paralavas are completely fused rocks and are mostly dark green or black in the sampled localities of the northeastern Ordos Basin (Figure 2j). They display uneven cinder, driblets structures, and vesicular texture (Figure $2 \mathrm{j}$ ). The paralavas are often found as thin veinlets that occur directly above the ashes or clinker derived from coal-burning (Figure 2b).
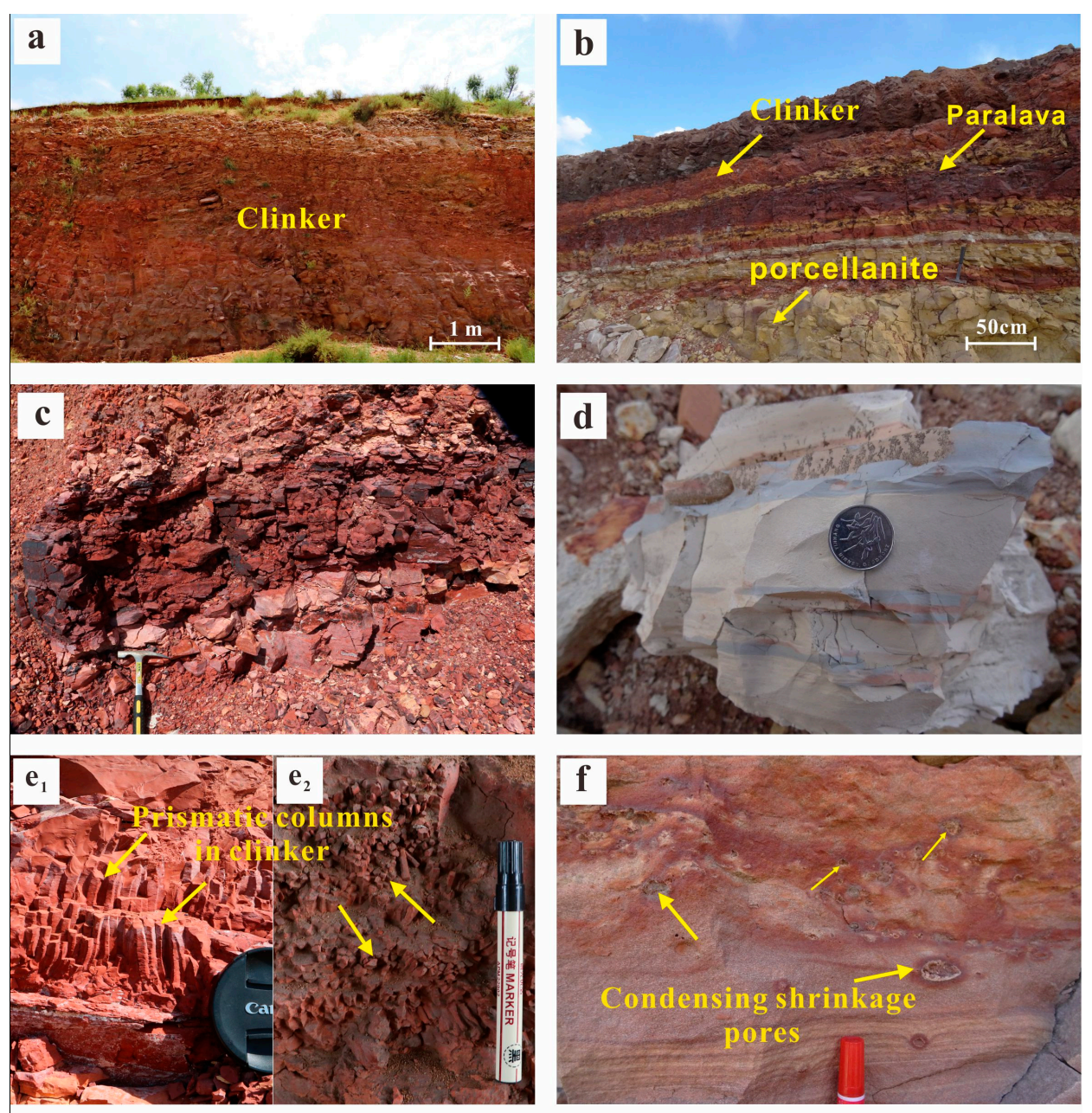

Figure 2. Cont. 

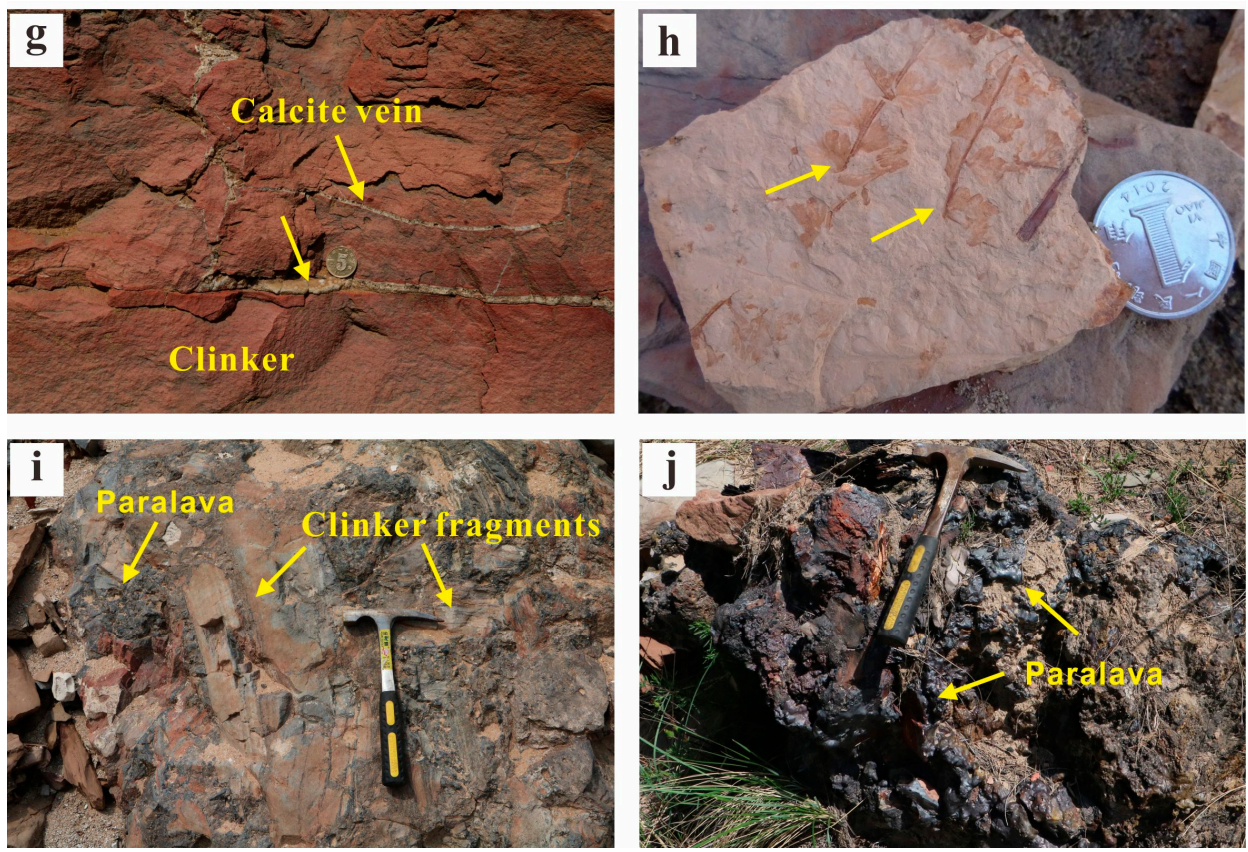

Figure 2. Field images of combustion metamorphic rocks. (a) Ocher red clinker. (b) The upper is multicolored clinker with a yellow porcellanite interlayer, the lower part is mainly yellow porcellanite.

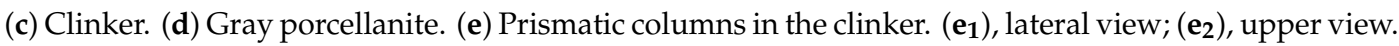
(f) Condensing shrinkage pores in clinker partially filled with calcite. (g) Calcite veins in clinker's fractures. (h) Traces of plant debris. (i) Combustion metamorphic breccias, clinker fragment cemented by massive black paralava. (j) Paralava, containing ferruginous hematite nodule. (a-g) located in BLT Area, (h-j) located in SSG Area.

In addition to the above typical CM rocks, coal fires can also form breccia and slag. Breccia, also known as combustion metamorphic breccia, contains clinker and unburnt rock fragments, which are cemented together by paralava (Figure 2i). Slag may form as a result of the consumption of ash, but the more common slag forms on the consumption of siderite or ankerite decomposition products. The majority of slags are Fe-rich rocks, whereas ashes are commonly Al-Si-rich and Fe-poor rocks. It ranges in color from black, brown, and violet in more siliceous types to shades of olive-green in less siliceous varieties [5].

The porcellanites were seen at the BLT Area. They are clay, marl, or shales completely recrystallized during combustion metamorphic alteration. They display ceramic or porcelain texture and are commonly dense, hard, and usually have a yellow or grayish-green color (Figure $2 \mathrm{~b}, \mathrm{~d}$ ).

\subsubsection{Macroscopic Characteristics of White Sandstones}

In the study area, there is a kind of porous and highly permeable white sandstone, which is notable for its obvious whiteness. Moreover, white sandstone is often found in association with clinker. It is often distributed on the roof or bottom of clinkers (Figure 3a,g). In the SSG-C section, the upper part is clinker or baked rock (Figure 3a). Affected by combustion metamorphism, the clinker is hard, dense, and mainly red, and there are condensing shrinkage pores in the clinker (Figure $3 b$ ). The lower part is white, medium-grained sandstone. It is relatively loose, porous, and weakly cemented (Figure 3e). The thickness of the layer is $10-50 \mathrm{~cm}$ (Figure 3d). The white sandstone shows no signs of baking, but within the white sandstone, localized red clinkers formed by combustion of organic matter are found (Figure 3f). In addition, there is a transition zone in the middle (Figure 3a), with a baked rock on the upper part and an unbaked rock on the lower part. It is also a color gradient zone, from top to bottom, the color gradually changes from red to white (Figure 3c). In the SSG-F' section, the white sandstone is located on the red clinker. The overall thickness of the white sandstone is about $2 \mathrm{~m}$. 
The coal seams that would have been involved in the combustion metamorphic events are hardly seen (Figure 3a,g). They may have been completely burned or may be buried.
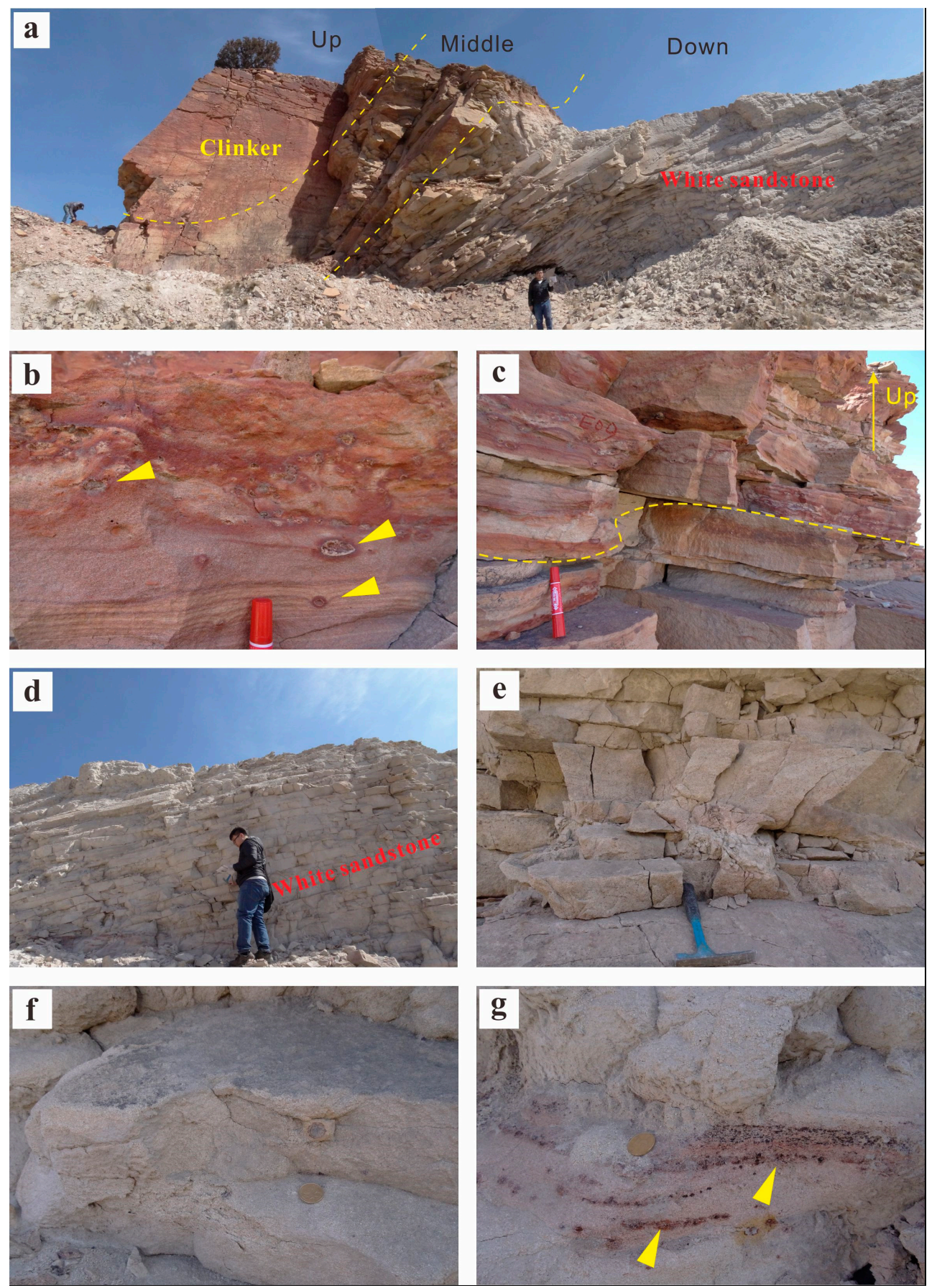

Figure 3. The appearance of white sandstone and CM rocks in the study area. (a) Outcrop from SSG-C section, white sandstone, and clinker. (b) Red clinker and condensing shrinkage pores (yellow arrow). (c) Middle color gradient zone. (d,e) A medium-thick layer of white sandstone. (f) White sandstone. (g) Signs of baking in white sandstone (yellow arrow). 


\subsection{Mineralogy of Combustion Metamorphic Rocks and White Sandstones}

\subsubsection{Rocks}

Four CM rock samples from the BLT, SSG, and DLT areas represent a variable degree of combustion metamorphism and were used to identify the mineral types through XRD. The BLT-S3 is paralava, completely melted, consisting of cordierite/sekaninaite, tridymite, cristobalite, mullite, hematite, and magnetite (Figure 4a). In the SSG section, the samples SSG-S1 are red clinker, which is not melted and retains some characteristics of the protolith resulting from the lower alteration degree. The SSG-S1 clinker sample consists of quartz, cordierite, tridymite, cristobalite, and mullite (Figure $4 \mathrm{~b}$ ). In the DLT section, sample DLT-S1 is clinker, partly melted, consisting of cordierite, tridymite, mullite, and quartz (Figure 4c). The sample DLT-S2 is paralava that consists of sekaninaite, cordierite, tridymite, clinoferrosilite, and magnetite (Figure 4d).
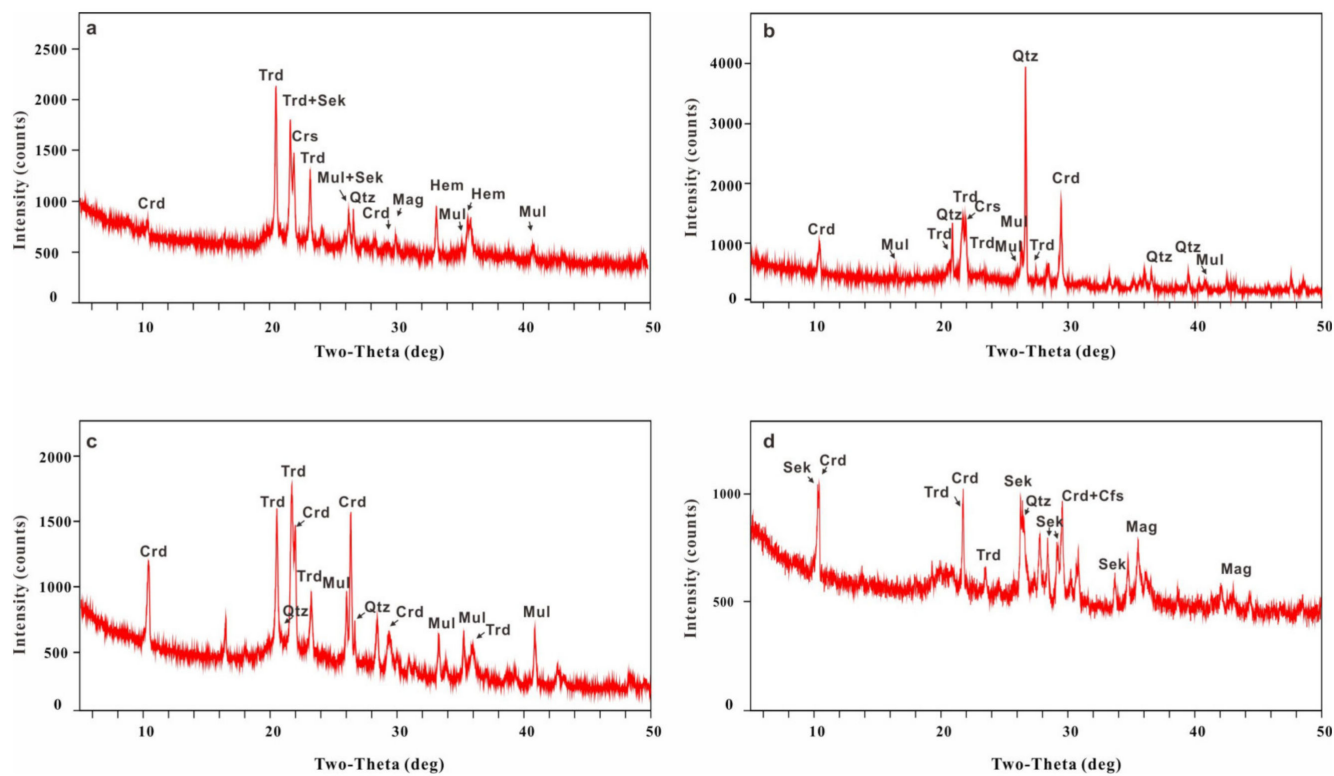

Figure 4. XRD diagrams of CM rocks from Ordos Basin. (a) Sample BLT-S3, paralava. (b) Sample SSG-S1, clinker. (c) Sample DLT-S1, clinker. (d) Sample DLT-S2, paralava. Quartz, Qtz; Tridymite, Trd; Cfs, Clinoferrosilite; Cristobalite, Crs; Cordierite, Crd; Sekaninaite, Sek; Hematite, Hem; Mullite, Mul; Magnetite, Mag.

\subsubsection{White Sandstones}

The white sandstone has fine to medium, subangular, well-sorted grains (Figure 5a). The content of quartz ranges from $60 \%$ to $75 \%$ in volume, while K-feldspar ranges from $15 \%$ to $25 \%$, rock fragments from $5 \%$ to $15 \%$, and other minerals, e.g., biotite, muscovite, zircon, and rutile, represent less than $1 \%$. Most feldspar is dissolved and kaolinized (Figure $5 \mathrm{~g}-1$ ), and dissolution pores can be often seen in feldspar (Figures $5 \mathrm{~g}$ and $6 \mathrm{a}$ ). The cement is mainly kaolinite (Figure 5c-f). SEM micrographs show that a large amount of kaolinite is mainly distributed among the grains and occurs in the form of vermicules and fragments (Figure $6 b-\mathrm{d}$ ). In addition, authigenic quartz can be seen between the particles (Figure 6e,f).

X-ray powder diffraction analysis of clay minerals shows that kaolinite dominates, accounting for $70 \%$ to $80 \%$ in weight. While illite $(8-17 \%)$ and chlorite $(10-12 \%)$ are less represented and montmorillonite is absent (Table 3). 

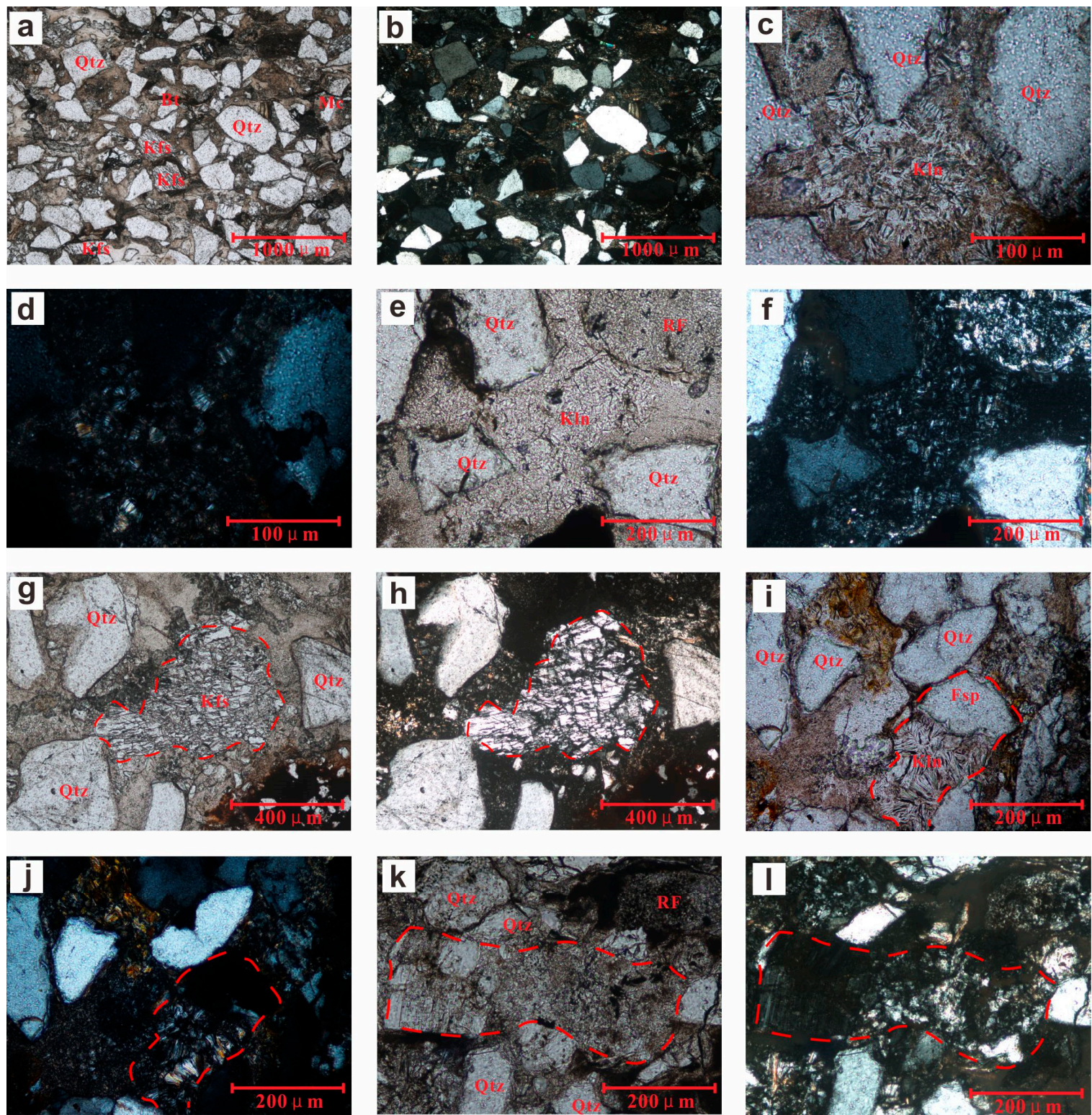

Figure 5. Thin-section micrographs of the white sandstone samples from Ordos Basin. (a,b) Sample SSG-C-7. (c,d) Sample SSG-C-4, Vermicular kaolinite distributed between particles. (e,f) Sample SSG-F-2, Kaolinite distributed between particles. (g,h) Sample SSG-F-2, K-feldspar particle (red square) is dissolved. (i,j) Sample SSG-C-4, K-feldspar particle (red square) is dissolved and transformed into kaolinite. (k,1) Sample BLT-5, same as i. (a,c,e,g,i, $\mathbf{k})$ Plane-polarized light, (b,d,f, $\mathbf{h}, \mathbf{j}, \mathbf{l})$ cross-polarized light. Qtz, quartz; Bt, biotite; Kln, kaolinite; Kfs, K-feldspar; Fsp, feldspar; Mc, microcline; RF, rock fragment.

Table 3. Clay mineral concentrations (wt.\%) of white sandstone from the Ordos Basin.

\begin{tabular}{cccccccc}
\hline Section & $\begin{array}{c}\text { Sample } \\
\text { No. }\end{array}$ & Lithology & $\begin{array}{c}\text { Illite } \\
(\mathbf{w t .} \%)\end{array}$ & $\begin{array}{c}\text { Kaolinit } \\
\text { (wt.\%) }\end{array}$ & $\begin{array}{c}\text { Chlorite } \\
(\mathbf{w t .} \%)\end{array}$ & $\begin{array}{c}\text { Montmorillonite } \\
\text { (wt.\%) }\end{array}$ & $\begin{array}{c}\text { Width of } \\
\text { Illitic Half } \\
\text { Peak }\left(\mathbf{\Delta 2}^{\circ}\right)\end{array}$ \\
\hline SSG & SSG-D-6 & white sandstone & 8.6 & 79.7 & 11.7 & $/$ & 0.335 \\
SSG & SSG-F-2 & white sandstone & 10.5 & 77.4 & 12.1 & $/$ & 0.270 \\
SSG & SSG-F-3 & white sandstone & 17.4 & 71.8 & 10.8 & $/$ & 0.265 \\
SSG & SSG-F-4 & white sandstone & 13.2 & 76.3 & 10.5 & $/$ & 0.402 \\
\hline
\end{tabular}



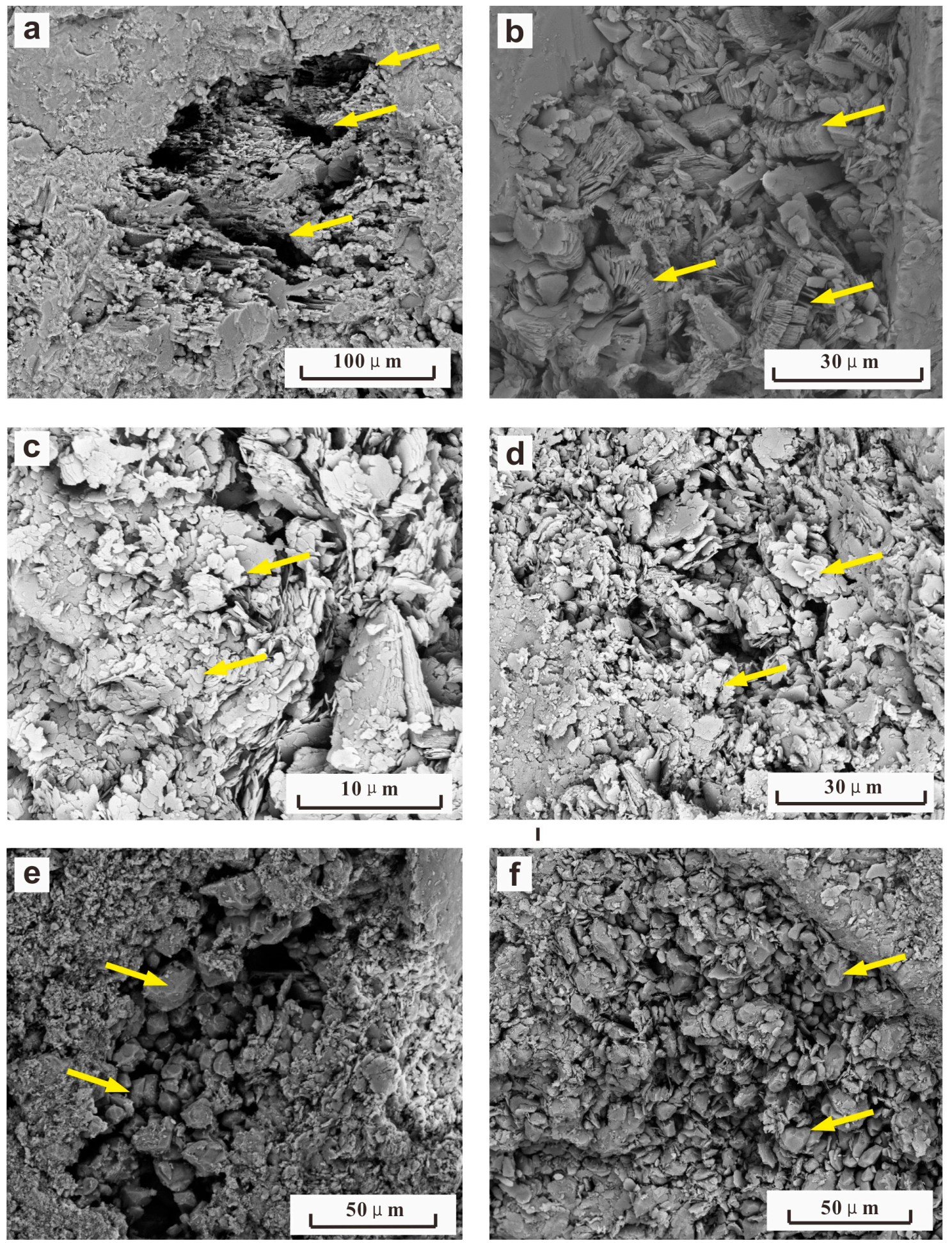

Figure 6. SEM micrographs of the white sandstones from Ordos Basin. (a) BLT-5, white sandstone, intragranular pores by feldspar dissolution. (b) SSG-D-2, white sandstone, vermicular kaolinite (yellow arrows). (c,d) SSG-C-4, white sandstone, sheet kaolinite (yellow arrow). (e) SSG-F-2, white sandstone, authigenic quartz (yellow arrow), and clay minerals. (f) SSG-C-7, white sandstone, the sheet kaolinite, and authigenic quartz (yellow arrow) are filled between the particles.

\subsection{Whole Rock Chemistry of the CM Rocks and White Sandstones}

Table 1 shows the major elemental concentrations for $\mathrm{CM}$ rock and white sandstone samples of this study. Whole rock analyses corresponding to clinker and paralavas show high $\mathrm{SiO}_{2}$ and $\mathrm{Al}_{2} \mathrm{O}_{3}$ 
contents. $\mathrm{SiO}_{2}$ concentrations are similar in $\mathrm{CM}$ rocks, ranging from $58.26 \%$ to $67.82 \% . \mathrm{Al}_{2} \mathrm{O}_{3}$ presents relatively high concentrations, from 16.22 to $23.32 \mathrm{wt} . \%$. Paralava samples S-6 and S-7 have lower $\mathrm{Al}_{2} \mathrm{O}_{3}$ concentration than other samples. In all of the samples, there is no apparent correlation between $\mathrm{SiO}_{2}$ and $\mathrm{Al}_{2} \mathrm{O}_{3}$. XRF analysis for $\mathrm{CM}$ rocks reveals low concentrations of $\mathrm{Na}_{2} \mathrm{O}$, about $0.2 \mathrm{wt} . \%$, except for paralava samples S-6 (1.22 wt.\%) and S-7 (1.58 wt.\%) from the DLT section. Clinker samples S-3 and S-8 show lower $\mathrm{Na}_{2} \mathrm{O}+\mathrm{K}_{2} \mathrm{O}$ concentrations (Figure 7b). The content of $\mathrm{CaO}$ is high in S-2, S-3, and S-7 of CM rock samples. This may be caused by calcareous cement in clinker or calcite veins in microcracking in paralava.
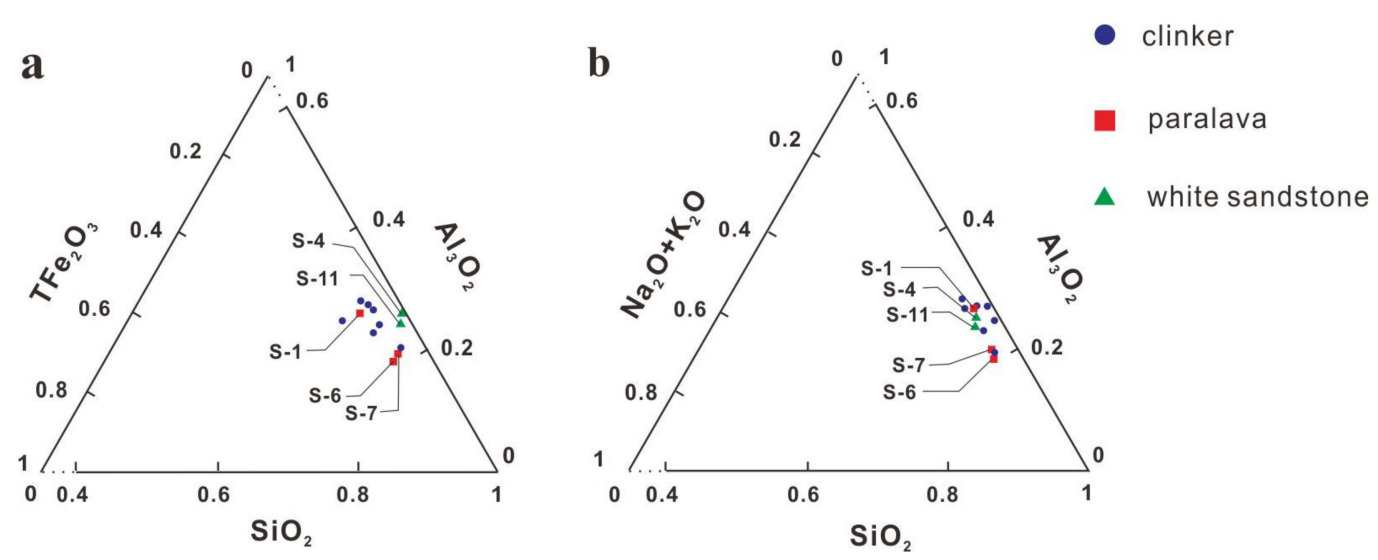

Figure 7. Ternary diagram illustrating the elemental compositions of the combustion metamorphic rocks and white sandstone samples from Ordos Basin. (a) $\mathrm{SiO}_{2}-\mathrm{Al}_{2} \mathrm{O}_{3}-\mathrm{TFe}_{2} \mathrm{O}_{3} ;$ (b) $\mathrm{SiO}_{2}-\mathrm{Al}_{2} \mathrm{O}_{3}-\left(\mathrm{Na}_{2} \mathrm{O}\right.$ $\left.+\mathrm{K}_{2} \mathrm{O}\right)$.

For white sandstone, $\mathrm{Al}_{2} \mathrm{O}_{3}$ content is $23 \%$, which is relatively higher than in other rocks. The content of $\mathrm{Na}_{2} \mathrm{O}+\mathrm{K}_{2} \mathrm{O}$ is 2.86 to $3.51 \mathrm{wt} . \%$, and the $\mathrm{Na}_{2} \mathrm{O} / \mathrm{K}_{2} \mathrm{O}$ ratio is 0.06 . The white sandstones contain comparable amounts of $\mathrm{SiO}_{2}$.

Figure 7a shows that clinker and paralava samples are richer in Fe than white sandstones. The red clinker S-8 has the highest concentration of $\mathrm{Fe}_{2} \mathrm{O}_{3}(8.65 \mathrm{wt} . \%)$. White sandstone samples S-4 and S-11 have lower iron concentrations than other samples, 0.66 and 0.91 wt. $\% \mathrm{Fe}_{2} \mathrm{O}_{3}$, respectively.

The paralava sample and clinker samples have trace element patterns typical of the upper continental crust, with positive $\mathrm{Pb}$ and $\mathrm{Nd}$, and negative $\mathrm{Nb}, \mathrm{Sr}, \mathrm{Eu}$, and $\mathrm{Ti}$ anomalies (Figure 8). However, the content of Th, U, Zr, and Hf in clinkers (BLT-13 and BLT-17) is 2 or 3 times higher than in the upper crustal. This may result from the presence of zircon and monazite in the clinker (Figure 8).

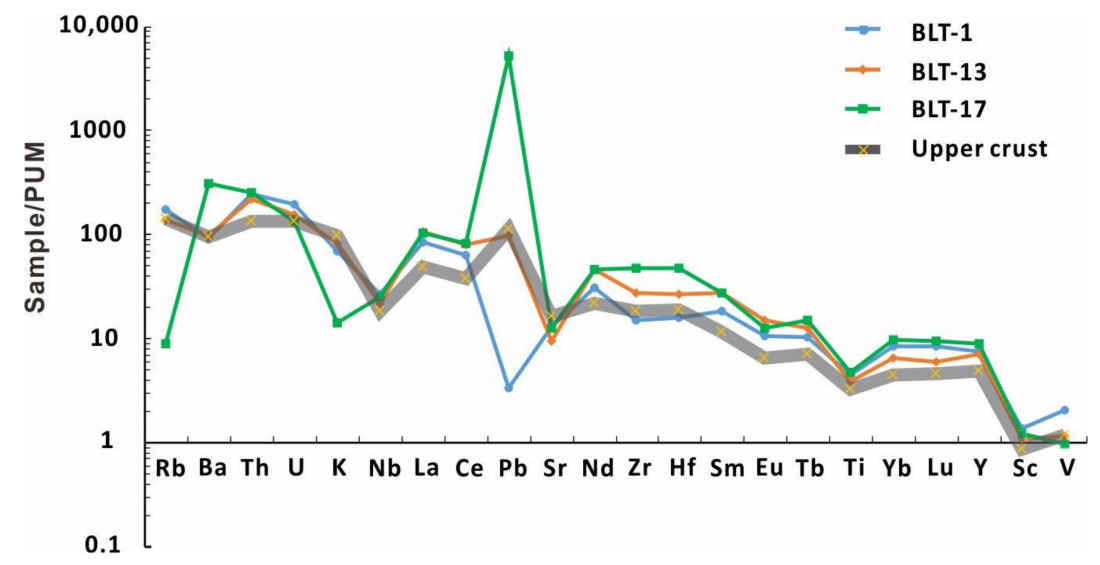

Figure 8. Trace element composition of whole-rock samples normalized to the primitive upper mantle (PUM) [85], upper continental crust [86]. 


\section{Discussion}

\subsection{Characteristics of Combustion Metamorphic Rocks in in Northeastern Ordos Basin}

$\mathrm{CM}$ rocks in the northeastern Ordos Basin show distinctive colors. Clinker normally appears brick-red in color (Figure 2). However, the color of the protolith of the Jurassic Ya'nan Formation is mainly bluish-gray, grayish-white, and grayish-black. The red color of the clinker is mainly caused by hematite impregnation occurred during CM alteration [56]. The rusty red of hematite and the ochre of limonite dominate colors on outcrops $[1,57,58]$. Heffern et al. (2004) suggested that red clinker is pigmented by iron oxidized during coal burning. Grapes (2010) proposed that the protolith covering the burning coal seams are first hardened and yellowed by oxidation of iron present as hematite or Fe-hydroxide. With continued heating, the yellowish colors change to darker, more intense hues of orange and red [5]. In addition, gases such as $\mathrm{CO}$ and $\mathrm{H}_{2}$ formed by coal pyrolysis under reducing conditions tend to cause the reduction of hydrous iron oxides to ferrous compounds in paralava and to magnetite $[1,5,87]$. Paralavas are gray or black as a result of the presence of magnetite.

Depending on the different baking temperatures of the rock, the CM rocks present different structural types, mineral compositions, and geochemical characteristics $[5,7,88]$. At the low-temperature stage $\left(<500{ }^{\circ} \mathrm{C}\right)$, the $\mathrm{CM}$ rocks mainly showed residual structures. They partly inherited from the textures of protoliths (e.g., bedding), and some traces of plant fragments were found in it. Some detrital minerals remain unchanged during the annealing within the mid-temperature interval $\left(\sim 500-800{ }^{\circ} \mathrm{C}\right)$, and it was noticed that some prismatic columnar jointing, pores, cavities, and fracture structures commonly appeared in the clinker. These structural heterogeneities were formed as the response to the mass loss and partial compaction of the pyrometamorphic rocks during coal combustion and annealing of sediments. Mullite with unoriented needles up to $0.5 \mu \mathrm{m}$ in length appeared [5]. For the high-temperature stage $\left(>800^{\circ} \mathrm{C}\right)$, delamination of large detrital phyllosilicates is apparent. Large areas of pore space form within the matrix caused by shrinkage resulting from dehydroxylation of illite/smectite [5]. At the high-temperature stage, when coal seams were totally or partially burned up, collapsed structures and related breccias occurred (e.g., driblet structures and vesicular structures) $[1,7,37,87]$. Vesicles are also present in paralava, with mineral zonal rims surrounding them. The presence of the downward orientation of driblets are clear evidence that the paralavas were liquid and emplaced by atmospheric pressure [89]. At temperatures of $\sim 1000{ }^{\circ} \mathrm{C}$ within paralava, feldspar and quartz are severely cracked. In the case of quartz, this results from the large volume change caused by inversion to tridymite/cristobalite [5].

Mineralogical composition of the studied samples showed that a set of newly formed pyrogenic minerals are present in $\mathrm{CM}$ rocks, including tridymite, cristobalite, cordierite, hematite, mullite and magnetite (Figure 4). Some of these minerals have been earlier identified as high-temperature phases associated with coal combustion $[5,13,16,88,89]$. High-temperature phases such as cristobalite and tridymite can be formed by direct polymorphic transformation of quartz [88,90]. Vassilev and Vassileva (1996), Baboolal et al. (2018), and Saxby (2000) suggest that cristobalite may also form when silica is liberated from clay minerals and mica above $900{ }^{\circ} \mathrm{C}[15,56,91]$. Cordierite is also considered to be a typical product of combustion metamorphism [5]. Ware et al. (2001) propose that hematite may be formed by oxidation of pyrite at temperatures below $400{ }^{\circ} \mathrm{C}$ [92] (Equation (1)). Hematite can crystallize in $\mathrm{CM}$ rocks when the temperature of coal combustion exceeds $500{ }^{\circ} \mathrm{C}$ [93]. The magnetite may have formed during the heating stage from the breakdown of phyllosilicates or possibly the melting of siderite decomposition products and persisted to the higher temperatures of paralava formation [5]. Furthermore, the presence of magnetite indicates a reducing environment (Equation (2)). The presence of abundant mullite in studied samples suggests that CM rocks experienced high-temperature alteration [13]. Mullite may be formed by high-temperature reactions during thermal 
decomposition of illite and kaolinite [94]. Reifenstein et al. (1999) and Saxby (2000) indicate that mullite begins to form from illite at around $1050^{\circ} \mathrm{C}$, and from kaolinite at $1100{ }^{\circ} \mathrm{C}[90,91]$.

$$
\begin{aligned}
& \text { Heat } \\
& 2 \mathrm{FeS}_{2} \text { (Pyrite) }+11 / 2 \mathrm{O}_{2}-\mathrm{Fe}_{2} \mathrm{O}_{3} \text { (Hematite) }+4 \mathrm{SO}_{2} \\
& 3 \mathrm{Fe}_{2} \mathrm{O}_{3} \text { (Hematite) }+\mathrm{H}_{2}=2 \mathrm{Fe}_{3} \mathrm{O}_{4} \text { (Magnetite) }+\mathrm{H}_{2} \mathrm{O}
\end{aligned}
$$

Whole-rock analyses of the major elements show that the content of iron in CM rocks is significantly higher than that in unbaked rocks (Figure 7a). This is due to the accumulation of iron in CM rocks during coal combustion, decomposition of siderite and pyrite, iron transport via hot gas jets and precipitation as fine-grained oxides. The paralava may be derived by fusion of a protolith mixture with a higher proportion of siderite nodule/ankerite-bearing ironstone [1,5]. In paralava samples S-6 and S-7, $\mathrm{Na}_{2} \mathrm{O}$ content is relatively high, which is caused by the occurrence of cordierites in the paralava, resulting in an elevation in alkali contents [5]. In addition, the high content of $\mathrm{CaO}$ in sample S-7 may be caused by the calcite vein in microcracks in paralava, and in some clinker samples the high $\mathrm{CaO}$ resulted from calcareous cements in the clinker. The loss on ignition (LOI) was high in the $\mathrm{CM}$ samples. The paralava sample S-7 showed a higher concentration of $\mathrm{CaO}$, indicating that calcite or other calcium-containing substances may have caused the higher LOI. At the same time, in clinkers, some residual clay minerals and calcareous cements led to high LOI because, in the study area, some clinkers were not melted but slightly baked.

In the study area, the paralavas have trace element patterns typical of upper continental crust (Figure 8), similar to that of the surrounding clinkers, implying that the paralava was formed by the melting of surrounding rocks.

\subsection{Origin of White Sandstone}

Notable examples of white sandstone facies are found in the Jurassic Navajo Sandstone and Permian White Rim Sandstone in Southeastern Utah (USA), and in the Buntsandstein and Rotliegend sandstones in Central Germany, where white sandstone beds are surrounded by red sandstone beds $[51-53,95,96]$.

Most studies suggest that white sandstone may have originated from a bleaching process of the original red sandstone protolith $[51,52,54,55]$. The white color of these white sandstones is caused by the removal of $\mathrm{Fe}^{3+}$. It has been suggested that the bleaching process of red sandstone occurs during mid-late diagenesis in the presence of reducing fluids and involves the reduction of $\mathrm{Fe}^{3+}$ to $\mathrm{Fe}^{2+}$, with dissolution and the removal of iron [52]. Furthermore, some studies suggested that bleaching of this type of red sandstone could be due to interaction with hydrocarbons (e.g., $\mathrm{CH}_{4}$ ) upwelling along faults into the rocks $[52,95,97,98]$. This later process has been proposed as a possible causal mechanism for the formation of white sandstone in the northeastern Ordos Basin [54,55,99-102]. However, a bleaching process does not seem likely for the white sandstone found in the northwestern Ordos Basin. Our investigations have revealed that the facies that was previously considered red sandstone in the study area is actually red clinker, formed by coal combustion, rather than a red sandstone protolith. The red color of this clinker is caused by the formation of ferric oxide during the combustion of coal seams [56,57]. The unmetamorphosed Jurassic sandstones in the Ordos Basin are mainly blue-gray and light gray [63]. Moreover, the dating of clinkers in Central Asia has shown that they mainly formed during the Quaternary period $[17,18,36]$. Therefore, for our study area, the origin theory of the bleaching of red sandstone during middle diagenesis is a temporal contradiction.

Field observations show that the white sandstone is porous, permeable, and weakly cemented. It is well exposed on the sides of valleys and gullies and is in contact with the red clinkers. As a result of weathering, some new minerals are formed. They are mainly clay minerals and usually cover the beds. However, because of their distribution close to CM rocks, they are sometimes mistaken for gas-vent minerals formed by the coal burning. The strongest evidence is that the mineral composition 
is different. Secondly, the CM rock has formed since the Quaternary period and was not formed by the recent coal fires. In addition, there are traces of atmospheric leaching on the surface of beds. Therefore, even if they are gas-vent minerals, they still cannot be preserved on the surface of the rock.

In the thin section, most feldspars in the white sandstone samples were strongly dissolved and kaolinized (Figure 5g,h). SEM micrographs showed that kaolinite is widely distributed and surrounds grains and fills dissolution pores. In addition, X-ray powder diffraction analysis of clay minerals in white sandstone revealed that the content of kaolinite is high, accounting for $70-80 \%$ in weight. It seems then that the abundance of kaolinite is the main cause of the color of the white sandstone facies in the Ordos Basin.

Our observation further revealed that kaolinite in the white sandstone samples occurs in the form of fragments, with small crystal shape and poor crystallinity (Figures $5 c-f$ and $6 b-d$ ). This fragmented and irregular distribution of kaolinite is generally considered a product of weathering by atmospheric rainwater under supergene conditions $[103,104]$. This, therefore, suggests that atmospheric rainwater was involved in the kaolinization process of the white sandstone analyzed in this study. This is confirmed by the hydrogen and oxygen isotopes of fluid inclusions $\left(\mathrm{H}_{2} \mathrm{O}\right)$ in calcite veins or calcium carbonate cement in white sandstone [104,105]. During the leaching process, the feldspar in the sandstone is dissolved, mainly forming kaolinite and a small amount of illite. The formation of chlorite is related to the original rock of the white sandstone, and the chlorite may be transformed from the iron-rich and magnesium-rich rock fragments during the diagenesis process. Wu et al. (2015) show $\delta^{18} \mathrm{O}(\mathrm{SMOW})$ of kaolinite ranging from $10.8 \%$ o to $13.6 \%$, with an average of $13.0 \%$, and $\delta \mathrm{D}$ (SMOW) of kaolinite ranging $-101.6 \%$ o to $-109.1 \%$, with an average of $-106.0 \%$ [105]. According to the $\delta \mathrm{D}$ and $\delta^{18} \mathrm{O}$ isotopic compositions diagram of kaolinite in white sandstone [105,106], it is considered that the formation of kaolinite in white sandstone is mainly caused by low-temperature hydrothermal alteration.

Our observation shows that in the study area, white sandstone systematically occurs in association with CM rocks (Figure 3). Based on this evidence and the mentioned elements testifying to the hydrothermal origin of kaolinization in the white sandstone in the northwestern Ordos Basin, we hypothesize that coal fire activity could have been the driver mechanism of the hydrothermal circulation.

Figure 9 shows a genetic model that may explain this process. Exposure of Jurassic clastic sedimentary units rich in coal seams in the northwestern Ordos basin created conditions favorable to the development of coal fires. The burning coal beds baked surrounding strata, and the adjacent strata of the burning center formed red combustion metamorphic rocks (e.g., red clinker, baked rocks). Atmospheric precipitation would have accumulated and may have been heated by the burning coal, promoting the activation of low-temperature hydrothermal circulation [45,107]. Circulation of hydrothermal fluids through the sandstones may have been favored by their permeability and the presence of fractures, promoting the dissolution and kaolinization of the feldspar contained in them (Equation (3)).

$$
\begin{gathered}
2 \mathrm{KAlSi}_{3} \mathrm{O}_{8}(\mathrm{~K} \text {-feldspar })+2 \mathrm{H}^{+}+\mathrm{H}_{2} \mathrm{O}=\mathrm{Al}_{2} \mathrm{Si}_{2} \mathrm{O}_{5}(\mathrm{OH})_{4}(\text { kaolinite })+2 \mathrm{~K}^{+}+4 \mathrm{SiO}_{2} \\
\mathrm{SO}_{2}+\mathrm{H}_{2} \mathrm{O}=\mathrm{H}_{2} \mathrm{SO}_{3} \\
2 \mathrm{H}_{2} \mathrm{SO}_{3}+\mathrm{O}_{2}=2 \mathrm{H}_{2} \mathrm{SO}_{4}
\end{gathered}
$$

In addition, it has been shown that coal seam combustion releases gases such as $\mathrm{SO}_{2}, \mathrm{NO}, \mathrm{CO}_{2}$, $\mathrm{H}_{2}$, and $\mathrm{CH}_{4}$, and this can promote the occurrence of acidic rain (Equations (4) and $\left.(5)\right)[108,109]$. Kaolinization and dissolution of feldspars are enhanced by the presence of acidic fluids [99,103]. This further points to a possible causal connection between coal fire activity and hydrothermal kaolinization of the Jurassic sandstone protolith in the Ordos Basin. 

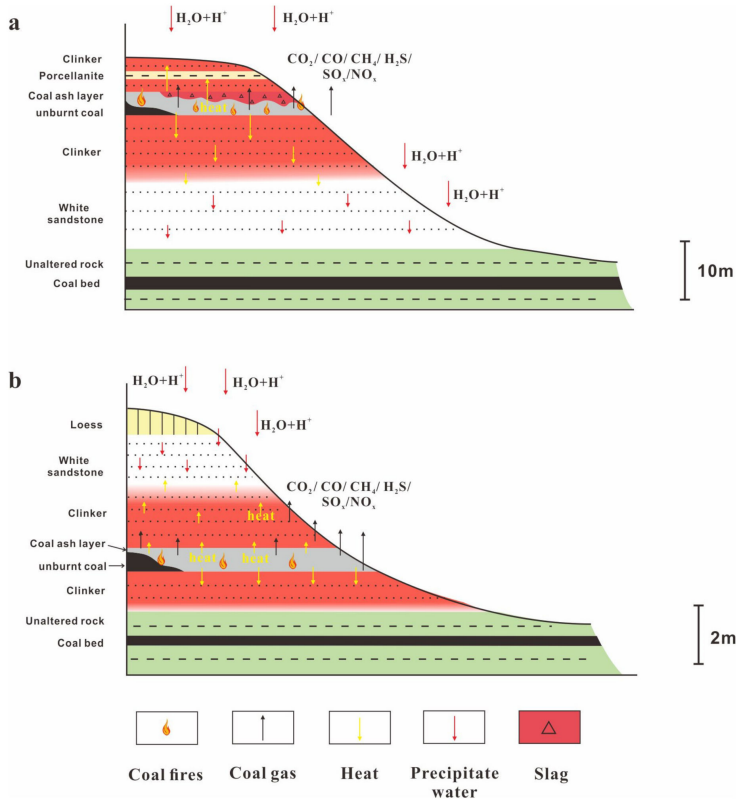

Figure 9. Evolution model of white sandstone. (a) The white sandstone lies below clinker; (b) The white sandstone sits above clinker.

\section{Conclusions}

In this study, we identified and characterized combustion metamorphic rocks outcropping in the northeastern Ordos Basin through macroscopic and microscopic observation and by applying a suite of analytical techniques. Based on mineral composition and the grade of thermal alteration, we identified the types of combustion metamorphic rocks that are found in the area, including clinkers, porcellanites, and paralavas. Specific features that characterize CM rocks in the Ordos Basin comprise columnar jointing and condensing shrinkage pores. Changes at the grain scale involve the formation of high-temperature minerals, which include tridymite, cristobalite, mullite, cordierite, and hematite. These indicate pyrometamorphic reactions during combustion processes.

Furthermore, we highlight the presence of peculiar white sandstone facies that is found in association with CM rocks. Mineralogical characterization of these facies suggests that its appearance is caused by extensive kaolinization of feldspars due to low-grade hydrothermal circulation. Given the observed close association of white sandstone and CM rocks, we hypothesize a genetic link between coal fires and the genesis of white sandstone facies in the northeastern Ordos Basin.

Author Contributions: Conceptualization, B.C. and Z.S.; data curation, Y.W., X.D., K.L., Y.Y., and M.W.; funding acquisition, Z.S.; investigation, B.C., X.D., K.L., and Y.Y.; resources, Y.W.; visualization, Y.W.; writing-original draft, B.C.; writing - review and editing, M.F. and Z.S. All authors have read and agreed to the published version of the manuscript.

Funding: This study is supported by the National 973 Project (No. 2015CB453001) and NSF grants (No. 41272131, 41572085) of the Chinese Ministry of Science and Technology.

Acknowledgments: Authors wish to thank Mingshi Feng (Chengdu University of Technology) for providing SEM analyses, Xiaoduan Wang, Bing Wu, and He Yin (Chengdu University of Technology) for helping during field-work.

Conflicts of Interest: The authors declare no conflict of interest.

\section{References}

1. Heffern, E.L.; Coates, D.A. Geologic history of natural coal-bed fires, Powder River basin, USA. Int. J. Coal Geol. 2004, 59, 25-47. [CrossRef]

2. Grapes, R.; Korzhova, S.; Sokol, E.; Seryotkin, Y. Paragenesis of unusual Fe-cordierite (sekaninaite)-bearing paralava and clinker from the Kuznetsk coal basin, Siberia, Russia. Contrib. Mineral. Petrol. 2011, 162, 253-273. [CrossRef] 
3. Stracher, G.B.; Prakash, A.; Sokol, E.V. Case Studies—Coal Fires; Elsevier: Amsterdam, The Netherlands, 2015; Volume 3, pp. 1-786.

4. Sokol, E.V.; Volkova, N.I. Combustion metamorphic events resulting from natural coal fires. In Geology of Coal Fires: Case Studies from Around the World; Stracher, G.B., Ed.; Geological Society of America: Boulder, CO, USA, 2007; Volume 18, pp. 97-115.

5. $\quad$ Grapes, R. Pyrometamorphism, 2nd ed.; Springer: London, UK, 2010; p. 331.

6. Stracher, G.B.; Prakash, A.; Sokol, E.V. Photographs and Multimedia Tours; Elsevier: Amsterdam, The Netherlands, 2012; Volume 2, pp. 1-5547.

7. Zhang, Y.; Zhang, X.; Hower, J.C.; Hu, S. Mineralogical and geochemical characteristics of pyrometamorphic rocks induced by coal fires in Junggar Basin, Xinjiang, China. J. Geochem. Explor. 2020, 213, 106511. [CrossRef]

8. Žáček, V.; Skála, R.; Dvořák, Z. Combustion metamorphism in the Most Basin, Czech Republic. In Coal and Peat Fires: A Global Perspective Volume 3 Case Studies_Coal Fires; Stracher, G.B., Prakash, A., Sokol, E.V., Eds.; Elsevier: Amsterdam, The Netherlands, 2015; Volume 3, pp. 161-199.

9. Vapnik, Y.; Sharygin, V.V.; Sokol, E.V.; Shagam, R. Paralavas in a combustion metamorphic complex: Hatrurim Basin, Israel. In Geology of Coal Fires: Case Studies from Around the World; Stracher, G.B., Ed.; Geological Society of America: Boulder, CO, USA, 2007; Volume 18, pp. 133-154.

10. Masalehdani, M.N.; Black, P.M.; Kobe, H.W. Mineralogy and petrography of iron-rich slags and paralavas formed by spontaneous coal combustion, Rotowaro coalfield, North Island, New Zealand. In Geology of Coal Fires: Case Studies from Around the World; Stracher, G.B., Ed.; Geological Society of America: Boulder, CO, USA, 2007; Volume 18, pp. 117-131.

11. Žáček, V.; Skala, R.; Dvořák, Z. Rocks and Minerals Formed by Fossil Combustion Pyrometamorphism in the Neogene Brown Coal Most Basin, Czech Republic. Bull. Mineral. Petrol. Oddel. Nar. Muz. 2010, 17, 1-2.

12. Laita, E.; Bauluz, B.; Yuste, A. High-temperature mineral phases generated in natural clinkers by spontaneous combustion of coal. Minerals 2019, 9, 213. [CrossRef]

13. Ribeiro, J.; Suárez-Ruiz, I.; Ward, C.R.; Flores, D. Petrography and mineralogy of self-burning coal wastes from anthracite mining in the El Bierzo Coalfield (NW Spain). Int. J. Coal Geol. 2016, 154-155, 92-106. [CrossRef]

14. Sharygin, V.V.; Sokol, E.V.; Belakovsky, D.I. Mineralogy and Origin of Fayalite-Sekaninaite Paralava: Ravat Coal Fire, Central Tajikistan. In Coal and Peat Fires: A Global Perspective Volume 3 Case Studies-Coal Fires; Stracher, G.B., Prakash, A., Sokol, E.V., Eds.; Elsevier: Amsterdam, The Netherlands, 2015; pp. 581-607.

15. Baboolal, A.A.; Knight, J.; Wilson, B. Petrography and mineralogy of pyrometamorphic combustion metamorphic rocks associated with spontaneous oxidation of lignite seams of the Erin Formation, Trinidad. J. S. Am. Earth Sci. 2018, 82, 181-192. [CrossRef]

16. Creelman, R.A.; Ward, C.R.; Schumacher, G.; Juniper, L. Relation between coal mineral matter and deposit mineralogy in pulverized fuel furnaces. Energy Fuels 2013, 27, 5714-5724. [CrossRef]

17. Novikova, S.; Sokol, E.; Khvorov, P. Multiple combustion metamorphic events in the Goose Lake Coal Basin, Transbaikalia, Russia: First dating results. Quat. Geochronol. 2016, 36, 38-54. [CrossRef]

18. Novikov, I.; Sokol, E. Combustion metamorphic events as age markers of orogenic movements in Central Asia. Acta Petrol. Sin. 2007, 23, 1561-1572.

19. Gur, D.; Steinitz, G.; Kolodny, Y.; Starinsky, A.; McWilliams, M. 40Ar39Ar dating of combustion metamorphism ("Mottled Zone", Israel). Chem. Geol. 1995, 122, 171-184. [CrossRef]

20. Song, Z.; Kuenzer, C. Coal fires in China over the last decade: A comprehensive review. Int. J. Coal Geol. 2014, 133, 72-99. [CrossRef]

21. Huang, L.; Liu, C. Products of combustion of the Yan'an formation coal seam and their characteristics in the northeastern Ordos Basin. Acta Geol. Sin. 2014, 88, 1753-1761.

22. Vapnik, Y.; Palchik, V.; Galuskina, I.; Banasik, K.; Krzykawski, T. Mineralogy, chemistry and rock mechanic parameters of katoite-bearing rock from the Hatrurim Basin, Israel. J. Afr. Earth Sci. 2018, 147, 322-330. [CrossRef]

23. Prakash, A.; Gens, R.; Prasad, S.; Raju, A.; Gupta, R.P. Coal Fires in the Jharia Coalfield, India. In Coal and Peat Fires: A Global Perspective Volume 2: Photographs and Multimedia Tours; Stracher, G.B., Ed.; Elsevier: Amsterdam, The Netherlands, 2012; Volume 2, pp. 153-177. 
24. Abad, I.; Sánchez-Gómez, M.; Reolid, M.; Sánchez-Vizcaíno, V.L. Pyrometamorphic Rocks in the Molinicos Basin (Betic Cordillera, SE Spain): Insights into the Generation of Cordierite Paralavas. Minerals 2019, 9, 748. [CrossRef]

25. Riihimaki, C.A.; Reiners, P.W.; Heffern, E.L. Climate control on Quaternary coal fires and landscape evolution, Powder River basin, Wyoming and Montana. Geology 2009, 37, 255-258. [CrossRef]

26. Reiners, P.W.; Riihimaki, C.A.; Heffern, E.L. Clinker geochronology, the first glacial maximum, and landscape evolution in the northern Rockies. GSA Today 2011, 21, 4-9. [CrossRef]

27. Querol, X.; Izquierdo, M.; Monfort, E.; Alvarez, E.; Font, O.; Moreno, T.; Alastuey, A.; Zhuang, X.; Lu, W.; Wang, Y. Environmental characterization of burnt coal gangue banks at Yangquan, Shanxi Province, China. Int. J. Coal Geol. 2008, 75, 93-104. [CrossRef]

28. Zhang, Y.; Hu, S.; Peng, J.; Zhang, T.; Li, J. Metamorphic products of coal combustion and its macroscopic models in North China. J. China Coal Soc. 2016, 41, 1705-1798.

29. Guan, H.; Van Ganderen, J.L.; Tan, Y.; Kang, G.; Wan, Y. The Environment Investigation and Study of Coal Seam Self-Combustion in Northern China; Coal Industrial Press: Beijing, China, 1997; pp. 27-29.

30. Stracher, G.B.; Prakash, A.; Schroeder, P.; McCormack, J.; Zhang, X.; Van Dijk, P.; Blake, D. New mineral occurrences and mineralization processes: Wuda coal-fire gas vents of Inner Mongolia. Am. Mineral. 2005, 90, 1729-1739. [CrossRef]

31. Kuenzer, C. Remote and In Situ Mapping of Coal Fires: Case Studies from China and India: Case Studies from China and India. In Coal and Peat Fires: A Global Perspective Volume 3 Case Studies-Coal Fires; Stracher, G.B., Prakash, A., Sokol, E.V., Eds.; Elsevier: Amsterdam, The Netherlands, 2015; Volume 3, pp. 57-93.

32. Huang, L.; Liu, C. Petrologic and REE geochemical characters of burnt rocks. Earth Sci. J. China Univ. Geosci. 2008, 33, 515-522.

33. Huang, L. Charaeters and Forming conditions of Burnt Rocks in Yan'an Formation of Northern Ordos Basin. Master's Thesis, Northwest University, Xi'an, China, 2008.

34. Ye, Y.G.; Wu, X.L.; Diao, S.B.; Jiang, B.N.; Zheng, X.H.; Dong, Y.R. Formation ages of burned metamorphic rocks from the Kuqa River section Tarim Basin. Mar. Geol. Quat. Geol. 1998, 18, 115-119. [CrossRef]

35. Sun, J.; Rui, M.A.; Shu, L. Petrologic Characteristics of Burnt Rocks from Coalfield Selfcombustion at Urumqi, Xinjiang. J. Nanjing Archit. Civ. Eng. Inst. 2001, 59, 15-19.

36. Novikov, I.S.; Sokol, E.V.; Travin, A.V.; Novikova, S.A. Signature of Cenozoic orogenic movements in combustion metamorphic rocks: Mineralogy and geochronology (example of the Salair-Kuznetsk Basin transition). Russ. Geol. Geophys. 2008, 49, 378-396. [CrossRef]

37. Sokol, E.V.; Novikova, S.A.; Alekseev, D.V.; Travin, A.V. Natural coal fires in the Kuznetsk Coal Basin: Geologic causes, climate, and age. Russ. Geol. Geophys. 2014, 55, 1043-1064. [CrossRef]

38. Yue, L.; Li, J.; Zheng, G.; Li, Z. Evolution of the Ordos Plateau and environmental effects. Sci. China Ser. D Earth Sci. 2007, 50, 19-26. [CrossRef]

39. Qiu, W.L.; Zhang, J.F.; Wang, X.Y.; Guo, Y.J.; Zhuang, M.G.; Fu, X.; Zhou, L.P. The evolution of the Shiwanghe River valley in response to the Yellow River incision in the Hukou area, Shaanxi, China. Geomorphology 2014, 215, 34-44. [CrossRef]

40. Deng, Q.; Feng, X.; Zhang, P.; Yang, X.; Xu, X.; Peng, S.; Li, J. Reverse fault and fold zone in the Urumqi range-front depression of the northern Tianshan and its genetic mechanism. Earth Sci. Front. 1999, 6, 191-201.

41. Gu, Z.K.; Shi, C.X. Dynamical characteristics of geomorphologic evolution of the basins covered by Pisha-sandstone in the eastern wing of the Ordos Plateau, China. J. Mt. Sci. 2018, 15, 1046-1056. [CrossRef]

42. Zhang, Y.; Liao, C.; Shi, W.; HU, B. Neotectonic Evolution of the Peripheral Zones of the Ordos Basin and Geodynamic Setting. Geol. J. China Univ. 2006, 12, 285-297.

43. Yuan, B.; Tang, G.; Zhou, L.P.; Hao, Q.; Li, F.; Lu, Z. Control action on the geomorphic differentiation in loess plateau and the formation of yellow river by cenozoic tectogenesis. Quat. Sci. 2012, 32, 829-838.

44. Zhao, H.; Liu, C.; Weng, W.; Gui, X.; Yue, L.; Wang, J.; Liang, M. Structural reverse and its significance to oil and gas in the east and west parts of Ordos Basin in the Neogene. Acta Pet. Sin. 2007, 28, 6-11.

45. Shi, Z.Q.; Yang, X.; Wang, Y.; Du, Y.; Xiao, K.; Duan, X. Theory of uranium mineralization caused by supergene hydrothermal fluid in coal-bearing basins:Evidences from Jurassic sandstone in southern Yili Basin and northeastern Ordos Basin, China. J. Chengdu Univ. Technol. 2016, 43, 703-718. 
46. Hoffmann, J.; Roth, A.; Voigt, S. Detecting Coal Fires in China Using Differential Interferometric Synthetic Aperture Radar (InSAR). In Proceedings of the FRINGE 2003 Workshop (ESA SP-550), Frascati, Italy, 1-5 December 2004; pp. 1-5.

47. Kuenzer, C.; Zhang, J.; Tetzlaff, A.; Van Dijk, P.; Voigt, S.; Mehl, H.; Wagner, W. Uncontrolled coal fires and their environmental impacts: Investigating two arid mining regions in north-central China. Appl. Geogr. 2007, 27, 42-62. [CrossRef]

48. Kuenzer, C.; Zhang, J.; Li, J.; Voigt, S.; Mehl, H.; Wagner, W. Detection unknown coal fires: Synergy of automated coal fire risk area delineation and improved thermal anomaly extraction. Int. J. Remote Sens. 2007, 28, 4561-4585. [CrossRef]

49. Song, Z.; Kuenzer, C. Spectral reflectance (400-2500nm) properties of coals, adjacent sediments, metamorphic and pyrometamorphic rocks in coal-fire areas: A case study of Wuda coalfield and its surrounding areas, northern China. Int. J. Coal Geol. 2017, 171, 142-152. [CrossRef]

50. Gorenc, M.; Chan, M. Hydrocarbon-induced diagenetic alteration of the Permian White Rim Sandstone, Elaterite Basin, southeast Utah. AAPG Bull. 2015, 99, 807-829. [CrossRef]

51. Gorenc, M.A. Petrophysical and Diagenetic Characteristics of the Permian White Rim Sandstone, Southeast Utah; University of Utah: Salt Lake City, UT, USA, 2015.

52. Beitler, B.; Chan, M.A.; Parry, W.T. Bleaching of Jurassic Navajo Sandstone on Colorado Plateau Laramide highs: Evidence of exhumed hydrocarbon supergiants? Geology 2003, 31, 1041-1044. [CrossRef]

53. Hilse, U.; Goepel, A.; Pudlo, D.; Heide, K.; Gaupp, R. Characterization of CO2-induced (?) bleaching phenomena in German red bed sediments by combined geochemical and evolved gas analysis. Geophys. Res. 2010, 12, 1684.

54. Zhang, L.; Liu, C.; Lei, K.; Sun, L.; Cun, X.; Du, F.; Deng, H. White Bleached Sandstone Genesis and Paleo-Weathered Crust Forming Environment of the Jurassic Yanan Formation in the Northeastern Ordos Basin. Acta Geol. Sin. 2017, 91, 1345-1359.

55. Ma, Y.; Liu, C.; Wang, J.; Zhao, J.; Fang, J.; Gui, X.; Yu, l. Effects of hydrocarbon migration and dissipation in later reformation of a basin:formation of Mesozoic bleached sandstone in northeastern Ordos basin. Oil Gas Geol. 2006, 27, 233-238.

56. Vassilev, S.V.; Vassileva, C.G. Occurrence, abundance and origin of minerals in coals and coal ashes. Fuel Process. Technol. 1996, 48, 85-106. [CrossRef]

57. Evans, M.; Heller, F. Environmental Magnetism: Principles and Applications of Enviromagnetics; Elsevier: New York, NY, USA, 2003; Volume 86, pp. 1-299.

58. Suárez-Ruiz, I.; Crelling, J.C. Applied Coal Petrology: The Role of Petrology in Coal Utilization; Elsevier: Amserdam, The Netherlands, 2008; pp. 1-388.

59. Wang, B.; Kaakinen, A.; Clift, P.D. Tectonic controls of the onset of aeolian deposits in Chinese Loess Plateau-A preliminary hypothesis. Int. Geol. Rev. 2018, 60, 945-955. [CrossRef]

60. Pan, B.T.; Hu, Z.B.; Wang, J.P.; Vandenberghe, J.; Hu, X.F.; Wen, Y.H.; Li, Q.; Cao, B. The approximate age of the planation surface and the incision of the Yellow River. Palaeogeogr. Palaeoclimatol. Palaeoecol. 2012, 356, 54-61. [CrossRef]

61. Sun, J.; Dong, Y. Middle-Late Triassic sedimentation in the Helanshan tectonic belt:Constrain on the tectono-sedimentary evolution of the Ordos Basin, North China. Geosci. Front. 2019, 10, 213-227. [CrossRef]

62. Ritts, B.D.; Hanson, A.D.; Darby, B.J.; Nanson, L.; Berry, A. Sedimentary record of Triassic intraplate extension in North China: Evidence from the nonmarine NW Ordos Basin, Helan Shan and Zhuozi Shan. Tectonophysics 2004, 386, 177-202. [CrossRef]

63. Liu, S.; Yang, S. Upper Triassic-Jurassic sequence stratigraphy and its structural controls in the western Ordos Basin, China. Basin Res. 2001, 12, 1-18. [CrossRef]

64. Ding, Z.L.; Sun, J.M.; Liu, T.S.; Zhu, R.X.; Yang, S.L.; Guo, B. Wind-blown origin of the Pliocene red clay formation in the central Loess Plateau, China. Earth Planet. Sci. Lett. 1998, 161, 135-143. [CrossRef]

65. Ao, W.; Huang, W.; Weng, C.; Xiao, X.; Liu, D.; Tang, X.; Chen, P.; Zhao, Z.; Wan, H.; Finkelman, R.B. Coal petrology and genesis of Jurassic coal in the Ordos Basin, China. Geosci. Front. 2012, 3, 85-95. [CrossRef]

66. Wang, S.; Zhang, W. Study on the formation, evolution and coalaccumulating regularity of the Jurassic Ordos Basin. Earth Sci. Front. 1999, 6, 147-154.

67. Liu, C.; Zhao, H.; Gui, X.; Yue, L.; Zhao, J.; An, X. Space-Time Coordinate of the Evolution and Reformation and Mineralization Response in Ordos Basin. Acta Geol. Sin. 2006, 80, 617-638. 
68. Zhang, Y.; Liao, C.; Shi, W.; Zhang, T.; Guo, F. Jurassic Deformation in and Around the Ordos Basin, North China. Earth Sci. Front. 2007, 14, 182-196. [CrossRef]

69. Grapes, R.; Zhang, K.; Peng, Z.-L. Paralava and clinker products of coal combustion, Yellow River, Shanxi Province, China. Lithos 2009, 113, 831-843. [CrossRef]

70. Huang, W.; Ao, W.; Weng, C.; Xiao, X.; Liu, D.; Tang, X.; Chen, P.; Zhao, Z.; Wan, H.; Finkelman, B. Characteristics of coal petrology and genesis of Jurassic coal in Ordos Basin. Geoscience 2010, 24, 1186-1197.

71. Xu, H.; Tang, D.Z.; Liu, D.M.; Tang, S.H.; Yang, F.; Chen, X.Z.; He, W.; Deng, C.M. Study on coalbed methane accumulation characteristics and favorable areas in the Binchang area, southwestern Ordos Basin, China. Int. J. Coal Geol. 2012, 95, 1-11. [CrossRef]

72. Gao, W.S. Coal petrographic characteristics of Shenmu-Dongsheng. Coal Geol. China 1991, 3, 36-38.

73. Wang, H.; Chu, X.; Liu, B.; Hou, H.; Ma, L. Atlas of the Paleogeography of China; Cartographic Publishing House: Beijing, China, 1985.

74. Wang, C.Y.; Sandvol, E.; Zhu, L.; Lou, H.; Yao, Z.X.; Luo, X.H. Lateral variation of crustal structure in the Ordos block and surrounding regions, North China, and its tectonic implications. Earth Planet. Sci. Lett. 2014, 387, 198-211. [CrossRef]

75. Hu, Z.B.; Pan, B.T.; Guo, L.Y.; Vandenberghe, J.; Liu, X.; Wang, J.P.; Fan, Y.L.; Mao, J.W.; Gao, H.S.; Hu, X.F. Rapid fluvial incision and headward erosion by the Yellow River along the Jinshaan gorge during the past 1.2 Ma as a result of tectonic extension. Quat. Sci. Rev. 2016, 133, 1-14. [CrossRef]

76. An, Z.; Kutzbach, J.E.; Prell, W.L.; Porter, S.C. Evolution of Asian monsoons and phased uplift of the Himalaya-Tibetan plateau since Late Miocene times. Nature 2001, 411, 62-66.

77. Jiang, F.; Fu, J.; Wang, S.; Zhao, Z. The age of the Yellow River passing through the Sanmen Gorge. J. Geomech. 2005, 11, 293-301.

78. Zhang, X.; Liu, Y.; Wang, S.; Liu, W.; Xue, W. On the chronology of the Yellow Rivers and the Yangtze Rivers. Mt. Res. 2018, 36, 661-668.

79. Wei, S. DEM drainage analysis of the Shanxi-Shaanxi gorge in the middle reaches of the Huanghe River and its neotectonic implications. Quat. Sci. 2008, 28, 288-298.

80. Liu, Y. Formation of the Yellow River terrace about 1. 1 Ma along the Shanxi-Shaanxi Gorge and its tectonic background. J. Palaeogeogr. 2018, 20, 477-488.

81. Guo, Z.; Sun, B.; Zhang, Z.; Peng, S.; Xiao, G.; Ge, J.; Hao, Q.; Qiao, Y. A major reorganization of Asian climate regime by the Early Miocene. Clim. Past 2008, 4, 153-174. [CrossRef]

82. Westaway, R. Active crustal deformation beyond the SE margin of the Tibetan Plateau: Constraints from the evolution of fluvial systems. Glob. Planet. Chang. 2009, 68, 395-417. [CrossRef]

83. Kuenzer, C.; Stracher, G.B. Geomorphology of coal seam fires. Geomorphology 2012, 138, 209-222. [CrossRef]

84. Cao, D.; Fan, X.; Guan, H.; Wu, C.; Shi, X.; Jia, Y. Geological models of Spontaneous Combustion in the Wuda Coalfield, Inner Mongolia, China. In Geology of Coal Fires: Case Studies from Around the World; Stracher, G.B., Ed.; Geological Society of America: Boulder, CO, USA, 2007; Volume 19, pp. $23-31$.

85. McDonough, W.F.; Sun, S.S. The composition of the Earth. Chem. Geol. 1995, 120, 223-253. [CrossRef]

86. Rudnick, R.L.; Gao, S. Composition of the Continental Crust. In The Crust; Rudnick, R.L., Ed.; Elsevier: Oxford, UK, 2003; pp. 1-66.

87. Heffern, E.L.; Reiners, P.W.; Naeser, C.W.; Coates, D.A. Geochronology of clinker and implications for evolution of the Powder River Basin landscape, Wyoming and Montana. In Geology of Coal Fires: Case Studies from Around the World; Stracher, G.B., Ed.; Geological Society of America: Boulder, CO, USA, 2007; Volume 18, pp. 155-175.

88. Matjier, R.H.; Ward, C.R.; Li, Z. Mineralogical Transformations in Coal Feedstocks during Combustion, based on Packed-Bed Combustor Tests Part 1: Bulk Coal and Ash Studies. Coal Combust. Gasif. Prod. 2012, 4, $45-54$.

89. Stracher, G.B. Gas Vent Mineralization and Coal Combustion; Elsevier: Amsterdam, The Netherlands, 2011; Volume 3, pp. 135-153.

90. Reifenstein, A.P.; Kahraman, H.; Coin, C.D.A.; Calos, N.J.; Uwins, P. Behaviour of selected minerals in an improved ash fusion test: Quartz, potassium feldspar, sodium feldspar, kaolinite, illite, calcite, dolomite, siderite, pyrite and apatite. Fuel 1999, 78, 1449-1461. [CrossRef]

91. Saxby, J.D. Minerals in coal. In Organic Matter and Mineralisation: Thermal Alteration, Hydrocarbon Generation and Role in Metallogenesis; Mastalerz, M., Glikson, M., Eds.; Kluwer Academic Publishers: London, UK, 2000; pp. 314-326. 
92. Ward, C.R.; Taylor, J.C.; Matulis, C.E.; Dale, L.S. Quantification of mineral matter in the Argonne Premium Coals using interactive Rietveld-based X-ray diffraction. Int. J. Coal Geol. 2001, 46, 67-82. [CrossRef]

93. Li, J.; Zhu, M.; Zhang, Z.; Zhang, K.; Shen, G.; Zhang, D. The mineralogy, morphology and sintering characteristics of ash deposits on a probe at different temperatures during combustion of blends of Zhundong lignite and a bituminous coal in a drop tube furnace. Fuel Process. Technol. 2016, 149, 176-186. [CrossRef]

94. French, D.; Dale, L.; Matulis, C.; Saxby, J.; Chatfiel, P.; Hurst, H.J. Characterization of mineral transformation in pulverized fuel combustion by dynamic high temperature x-ray diffraction analyzer. In Proceedings of the 18th Pittsburgh International Coal Conference, Newcastle, Australia, 3-7 December 2001.

95. Chan, M.; Parry, W.; Bowman, J. Diagenetic Hematite and Manganese Oxides and Fault-Related Fluid Flow in Jurassic Sandstones, Southeastern Utah. AAPG Bull. 2000, 84, 1281-1310.

96. Beitler, B.; Parry, W.T.; Chan, M.A. Fingerprints of Fluid Flow: Chemical Diagenetic History of the Jurassic Navajo Sandstone, Southern Utah, U.S.A. J. Sediment. Res. 2005, 75, 547-561. [CrossRef]

97. Garden, I.; Guscott, S.; Burley, S.; Foxford, K.; Walsh, J.J.; Marshall, J. An exhumed palaeo-hydrocarbon migration fairway in a faulted carrier system, Entrada Sandstone of SE Utah, USA. Geofluids 2001, 1, 195-213. [CrossRef]

98. Parry, W.; Chan, M.; Nash, B. Diagenetic characteristics of the Jurassic Navajo Sandstone in the Covenant oil field, central Utah thrust belt. AAPG Bull. 2009, 93, 1039-1061. [CrossRef]

99. Ma, Y.; Liu, C.; Zhang, F.; Zhao, J.; Yu, L.; Huang, L. Genesis and Characteristics of the Dongsheng Kaolin Deposits in Ordos Basin. J. Jilin Univ. 2007, 37, 929-936.

100. Ma, Y.; Liu, C.; Zhao, J.; Huang, L.; Yu, L.; Gui, X.; Fang, J.; Wang, J. Relationship between sandstone bleaching and gas escape in northeast ordos basin. Sci. China Ser. D Earth Sci. 2007, 37, 127-138.

101. Song, T.; Liu, L.; Wang, Y.; Liu, N.; Yu, M. Characteristics and genesis of the bleached Pisha sandstone in Ordos Basin. Oil Gas Geol. 2014, 35, 679-685.

102. Tan, Y.; Wang, J.; Gao, D.; He, Y.; Han, P. Alteration characteristics and genetic mechanisms of Yan'an Formation sandstone bleaching in Dongsheng area. Nat. Gas Explor. Dev. 2017, 40, 17-23.

103. Liu, H.; Ding, B.; Liu, Z.; Zhang, X.; Pan, C. Genesis of strong kaolinization in ore-bearing sandstone from Mengqiguer uranium deposit, Yili Basin, China. Acta Mineral. Sin. 2017, 37, 40-48.

104. Ding, B.; Liu, H.; Yang, S.; Yang, L.; Ren, Z.; Li, P.; Zhang, B. Discussion on the genesis of kaolinite in white sandstone of Yanan Formation in the northeast of Ordos Basin. Geol. Rev. 2019, 65, 51-52.

105. Wu, B.; Wei, A.; Liu, C.; Song, Z.; Hu, L.; Wang, D.; Cun, X.; Sun, L.; Luo, J. Stable isotope tracing on the formation of white sandstone in Yan'an Group, northern Ordos Basin, and its geological significance. Earth Sci. Front. 2015, 22, 205-214.

106. Xu, B.; Shao, Y. The studies on hydrogen and oxygen isotopes in Kaolin deposits in Zhejiang Province. Sci. Geol. Sin. 1986, 1, 90-96.

107. Shi, Z.; Chen, B.; Wang, Y.; Hou, M.; Jin, X.; Song, H.; Wang, X. A linkage between uranium mineralization and high diagenetic temperature caused by coal self-ignition in the southern Yili Basin, northwestern China. Ore Geol. Rev. 2020, 121, 1-14. [CrossRef]

108. Singh, A.K.; Mondal, G.C.; Kumar, S.; Singh, K.K.; Kamal, K.P.; Sinha, A. Precipitation Chemistry and Occurrence of Acid Rain Over Dhanbad, Coal City of India. Environ. Monit. Assess. 2007, 125, 99-110. [CrossRef]

109. Stracher, G.B.; Taylor, T.P. Coal fires burning out of control around the world: Thermodynamic recipe for environmental catastrophe. Int. J. Coal Geol. 2004, 59, 7-17. [CrossRef]

Publisher's Note: MDPI stays neutral with regard to jurisdictional claims in published maps and institutional affiliations.

(C) 2020 by the authors. Licensee MDPI, Basel, Switzerland. This article is an open access article distributed under the terms and conditions of the Creative Commons Attribution (CC BY) license (http://creativecommons.org/licenses/by/4.0/). 